Rhode Island College

Digital Commons @ RIC

$12-10-2020$

\title{
Terrorism, Surveillance, and Police Powers: An Analysis of Political Ideology and Trust in Government
}

Christopher Andrew Martin

Follow this and additional works at: https://digitalcommons.ric.edu/etd

\section{Recommended Citation}

Martin, Christopher Andrew, "Terrorism, Surveillance, and Police Powers: An Analysis of Political Ideology and Trust in Government" (2020). Master's Theses, Dissertations, Graduate Research and Major Papers Overview. 334.

https://digitalcommons.ric.edu/etd/334

This Thesis is brought to you for free and open access by the Master's Theses, Dissertations, Graduate Research and Major Papers at Digital Commons @ RIC. It has been accepted for inclusion in Master's Theses, Dissertations, Graduate Research and Major Papers Overview by an authorized administrator of Digital Commons @ RIC. For more information, please contact digitalcommons@ric.edu. 


\title{
TERRORISM, SURVEILLANCE, AND POLICE POWERS: AN ANALYSIS OF POLITICAL IDEOLOGY AND TRUST IN GOVERNMENT
}

\author{
By Christopher Martin
}

\section{A Thesis Submitted in Partial Fulfillment}

Of the Requirements for the Master of Justice Studies in

The Department of Sociology

The School of Arts and Sciences

Rhode Island College

2020 


\begin{abstract}
In the wake of the September 11 terrorist attacks, law enforcement in the United States began to employ powers and tactics that infringe upon the civil liberties of the suspects that they targeted. Though some of these uses have been challenged and reversed in the courts, there is still a portion of the population that believes that tactics like these, even up to torture, have been justified to combat terrorism. This study seeks to use General Social Survey data about people's views of the use of expanded police and surveillance powers to combat terrorism to compare these with people's age, sex, race, education, political ideology, and trust in different branches of the government. This will improve our understanding of who puts more emphasis on security over civil liberties when it comes to terrorist suspects.

Through this analysis, it is found that political ideology was not as important as was thought in the literature. It was found that confidence in the military was the strongest indicator of people favoring policies that expanded surveillance and gave increased power to go after terrorist suspects.
\end{abstract}


Table of Contents

Introduction 1

Literature Review 3

Methods 15

$\begin{array}{ll}\text { Findings } & 21\end{array}$

Discussion 32

Conclusion $\quad 34$

References $\quad 36$

Appendix 45 


\section{Introduction}

The terrorist attacks of September 11, 2001 and subsequent attacks have made terrorism and the response to terrorism a more widely known issue in everyday lives. It has also sparked much debate as to the ways in which we should combat these threats and if our current systems of law enforcement are capable of handling these types of criminals. Some have called for an increase in the powers of the organizations that are tasked with hunting down terrorist suspects, allowing them greater abilities to track down people who are suspected of terrorist activity. These proposals sometimes come at the cost of the civil liberties of those who are suspected of engaging in terrorist activity.

September 11, 2001 is a day that no one saw coming. The early morning news reported their stories normally and everything seemed to be normal. This all changed in the midmorning when the planes began to hit their targets and people were unaware of what was happening. By nighttime there were thousands thought dead as a part of the attacks, no one had claimed responsibility as of yet and many in the United States were calling for revenge (Barron 2001). The president said this in his address to the nation that evening:

The search is underway for those who were behind these evil acts. I have directed the full resources of our intelligence and law enforcement communities to find those responsible and to bring them to justice. We will make no distinction between the terrorists who committed these acts and those who harbor them (Bush 2001)

This rhetoric suggests that the United States was prepared to go after people suspected of these acts with all of its resources and ability.

As part of the fighting and intelligence gathering comes the policy detaining people suspected of terrorism and those captured on the battlefield. This new kind of war has presented 
the United States with a unique problem when it comes to detainment of the prisoners of war. In previous wars, those that had a declared start and an expected end of hostilities, prisoners would be exchanged at the end of hostilities and then go home (Savage 2018). This is not the case when you are not fighting a nation and there is no one to formally surrender. This has led to an issue where there is no clear way to release prisoners because it is feared by many that they will join new groups when released, but there is not enough evidence (or the evidence would not stand up in court) to convict these prisoners in a civilian court. There has been a shift in recent years to trying these people in a criminal court to get more stable convictions, but there are still some detainees who the United States must come up with another solution for.

Another policy that was implemented by the United States was the usage of "enhanced interrogation" techniques to gain information from prisoners, these techniques have been described as torture, and included things such as waterboarding, shackling detainees in uncomfortable positions, and keeping them awake for days at a time (Johnson, Mora, and Schmidt 2016). These techniques not only had debated efficacy in terms of gaining information, but they also hurt the United States internationally as some other nations did not trust the United States' detention of prisoners and the rhetoric of terrorists began to emphasize these techniques in their recruitment. Some CIA operatives and high-ranking officials in the Bush administration, including the former president, face potential legal issues if they travel to countries that have open investigations into these actions (Johnson, Mora, and Schmidt 2016).

Despite this, support for these programs has remained popular, with about half of the country believing that torture can be justified when going after terrorist suspects, and U.S. President Donald Trump has stated that he believes that torture works. This would imply that there is something less tangible that is leading to people to show support for more extreme 
measures when it comes to terrorist suspects. This support tends to follow along partisan lines, with republicans supporting greater powers to go after terrorists. Is this all that is going on here, or are there other variables, such as trust or race that are affecting these opinions?

This study seeks to examine the popularity of programs, such as surveillance and detention, in the general public using GSS data collected in 2016 in order to answer these questions. Additionally, these variables will also be examined while looking at the political ideology of the people who hold these beliefs, and their views on the government in order to understand what may contribute to these differing opinions.

I begin with a review of the literature that examines the various laws and policies that have been enacted by the United States and some other countries that have expanded police powers when it comes to terrorism and some opinion numbers about these policies. I then briefly discuss my methods. After this I go through the data by each individual variable before a multiple regression to see which is most correlated. This analysis aimed at answering the questions of: does how political views correlate with views on anti-terror and surveillance policies? And how does trust in the different parts of the government correlate with views on anti-terror and surveillance policies? I conclude with the implications of these findings.

\section{Literature Review}

\section{USA PATRIOT ACT and the FISA Court}

The groundwork for United States law on how to respond to terrorist acts and terrorist suspects in the wake of the September 11 attacks is the USA PATRIOT Act of 2001. The Patriot Act greatly expands the capacity of government agents to collect information from records of all 
kinds including business, school and library records in Article V by expanding FBI ability to get these records so long as it is not based on activity protected by the first amendment; and by amending the General Education Provisions Act and the National Education Statistics Act of 1994 so that disclosures can be made to the Attorney General for Terror suspects (USA PATRIOT Act, 115 Stat. 272 2001). The government attempted to frame the act as being good for both liberty and security. The logic of the government was that security is necessary for liberty and that terrorists act to threaten security (Pikowsky 2002). This logic goes further to say that because the Patriot Act attempts to stop these terrorists and create greater security, it therefore fosters greater levels of liberty (Simone 2009).

The Patriot Act also greatly expanded the FISA (Federal Intelligence Surveillance Act) courts by adding new judges, some of these judgers were required to be in Washington D.C. so that they could be more easily reached by government agencies. It also lifted restrictions on requirements for surveillance warrants from the court (Pikowsky 2002). The FISA courts, as originally constructed by their 1978 establishing law, were designed to allow for the legal intelligence gathering from foreign entities or the agents of these entities by agents of the United States government. The court was given this specific purpose as it was supposed to distinguish between this information being used for "foreign intelligence purposes" and not for "law enforcement purposes" (Funk 2007). Surveillance that was to be conducted under the umbrella of foreign intelligence has less protections and therefore fewer legal requirements for these warrants.

Since the Patriot Act's passing, FISA courts have greater range to allow for roving surveillance and the standards of the court for granting surveillance have been lowered. Another notable change to the ways the FISA courts are used is that it had become acceptable to use 
information gathered by a FISA warrant in a criminal court so long as intelligence was the primary purpose of the surveillance when the criminal evidence was obtained (Henderson 2002). This has led to a greater use of the FISA courts as a general tool to pursue terror suspects. There are still some restrictions on the surveillance authorizations, US citizens have a higher bar to clear when getting a FISA authorization (Johnson 2008). The FISA courts expansion are an increase in surveillance that has come about in the wake of September 11.

\section{General Surveillance}

The FISA courts do not represent the only ways in which the federal government has increased their surveillance since 2001. With the rise in the use of social media, there are a host of companies collecting data from those sites. The government can use this data to track people and movements that form on social media (Scott 2017). This collection of data is perfectly legal since the people are sharing it willingly and with no reasonable expectation of privacy once it is posted on these sites. As a result of this, the government has justified the use of this data to track movements such as Black Lives Matter and to track individuals they deem dangerous (Scott 2017).

This increased level of surveillance has also been seen in areas that have traditionally been given greater protections under the law. In late October of 2001, Attorney General John Ashcroft issued an order that allowed for the monitoring of attorney-client conversations of those incarcerated if there is a "reasonable suspicion" that this communication will lead to further acts of terror (Pogdor and Hall 2003). This surveillance requires a court order and notification of both parties of this surveillance taking place. Regardless of this requirement, some defense attorneys were upset by this new rule as they saw it as infringing on a fundamental part of communication 
and that it would lead to less communication after the notification is received (Pogdor and Hall 2003). Pogdor and Hall concluded that even though these restrictions were short lived, such actions would have a chilling effect on lawyers' willingness to take on terror cases.

These increases to surveillance programs are only a part of the government's powers that have been exercised in the wake of the September 11 attack. The government began to define fighting terrorists using the terminology of war. This so called "war on terror" is the rationale for this increased surveillance on people who were seen as combatants. This logic made civil liberties for terrorist suspects a "luxury" that could not be afforded to those who sought to attack the United States (Baker 2003). Attorney General Ashcroft continued this logic by suggesting that people who were concerned over the civil liberties of terrorist suspects were treasonous (Braml 2003). Baker found that this logic has led to some practices that substantially limited the rights of those accused of terrorism. Additionally, the perception of people of Middle Eastern descent as being terrorists has led to more racial profiling (Baker 2003; Lobel 2002).

One form of surveillance that has been expanded in the wake of the terror attacks of the $21^{\text {st }}$ century is the use of CCTV cameras in public spaces. Hempel and Topfor (2009) examined this expansion in the United Kingdom, France, and Germany. They found that all of these countries passed laws that expanded the CCTV network and made it easier for law enforcement to tap into. It was framed by the government as being a necessary step to keep the public safe (Hempel and Topfor 2009)

Another area of surveillance that was expanded upon was the capacity of governments to collect data on internet usage. This expansion has been additionally augmented by the information sharing that goes on between countries, allowing for tracking of people's activity (Brown and Korff 2009). With the close-knit and highly cooperative nature in Europe this has 
especially been the case there as they are very willing to share this information between agencies of different nations (Brown and Korff 2009)

\section{Court Responses}

This expansion has largely been spearheaded by the executive branch in the United States. De Londras and Davis (2010) found that laws like the USA PATRIOT Act gave the executive agencies the powers that they deemed necessary to fight the war on terror.

Additionally, De Londras and Davis (2010) also found that the executive branch claimed that the courts did not have the authority to interfere with detentions of terrorist suspects as it fell under the President's war powers.

The courts did not agree that they could not review the methodology of the executive branch to fight terrorism, and this led to decisions like the Hamdi and Rasul cases. In Rasul v. Bush (2004), a group of detainees from Kuwait were sent to Guantanamo Bay for detention. Three detainees, including Shafiq Rasul, filed for a writ of habeas corpus in federal court to have their detention declared unconstitutional. Their detention was upheld by the district court and the circuit court, citing that they did not have jurisdiction in these cases. The supreme court disagreed and ruled that detainees in Guantanamo Bay have the ability to challenge their detention there.

In Hamdi v. Rumsfeld (2004), Yaser Hamdi was captured in Afghanistan and was classified as an "enemy combatant" for allegedly taking up arms against the United States and joining the Taliban. This designation allowed Hamdi to be subject to a military tribunal and military law despite being an American citizen. Due to this, Hamdi was held for two years without charge and the lower courts deferred to the executive's perspective that the authorization 
of the use of force in Afghanistan was sufficient to justify both the detention and Hamdi's enemy combatant designation. The Supreme Court overturned the lower courts and held that being labeled enemy combatant was not sufficient to remove Hamdi's ability to contest his detention.

The lower courts seemed to be unaffected by the changes to the laws that came about after the September 11 attacks. Shortell and Smith (2005) found that federal cases against terrorism in their data set, pre-9/11 $86 \%$ of outcomes were favorable to the prosecution and post9/11 81\% were favorable to the prosecution. Shortell and Smith (2005) concluded from this figure that there had been no significant change in the likelihood that terrorists would be ruled against in the courts.

Having an independent judiciary is linked to having lower levels of terrorist actions (Findley and Young 2011); and while the favoring of prosecution in criminal cases has remained unchanged (Shortell and Smith 2005), the judiciary has frequently deferred to the executive branch's assertions on cases. Banks and Tauber (2014) found that district judges deferred to the executive's opinions in $3 / 5$ of the cases before them concerning terrorism and surveillance under the Patriot Act. This deference is also linked to several other variables in the parties in the court and the other branches of government. Banks and Tauber found that while the ideology of the judge did not impact decisions; when the senate was more conservative, the judiciary was more willing to defer to their opinions in civil liberties cases.

\section{Rally Around the Flag Effect}

The September 11 attacks created a surge of public support for the United States government's responses to security issues and going after the terrorists. This "rally around the flag" effect saw Americans united against a common threat and in fear of potentially more 
attacks (Huddy, Feldman, and Weber 2007; Ojeda 2016; Cole, Kincaid, and Parkin 2002). This is explained by the salience of terrorism becoming higher to many Americans after seeing the September 11 attacks and wanting to have security from future attacks (Deflem and McDonough 2015). Terrorism was brought into the public's view by the attack and raised the public support for programs to help to find and prevent future terrorist attacks (Deflem and McDonough 2015; Haggerty and Gazso 2005; Lewis 2005). This increased public support for the government and these policies quickly waned after the September 11 (Ojeda 2016; Deflem and McDonough 2015). Within three months of the attack, confidence in the government was at $68 \%$ and people willing to investigate threats regardless of privacy concerns was at $77 \%$. These figures dropped to $45 \%$ confidence and $66 \%$ willing to investigate after the two-year mark (McArdle et al 2012). The "rally around the flag" effect is found not only in the United States after 9/11, but in the wake of other attacks that have happened since the September 11 attacks in other places. This was found to be the case with the 3/11 attack in Madrid orchestrated by an Al-Qaeda inspired cell on March 11, 2004(Dinesen and Jaeger 2013) The cell attacked the Madrid commuter rail system, killing 191 and wounding approximately 2,000. Dinesen and Jaeger found that there was a surge in public support for the government in Spain after this attack, but that increased public support returned to normal levels within a few months after the attack. In the weeks before the attack trust in the Spanish national government was at $43 \%$ among Spanish citizens. This figure went up to $58 \%$ in the immediate aftermath of the attack, but it was back to $43 \%$ at about a year after the attack.

\section{Public Opinion of Anti-Terror Policies}


increase in trust may be one of several explanations in the wake of the 9/11 attack.

Chanley (2002) finds that an increase in interest in international relations leads to a greater trust in the government. Chanley found this by controlling for the other variables in her study, such as presidential approval and consumer sentiment, and the relationship between interest in international relationship. Chanley uses this to explain part of why the trust in government may have increased in the wake of the September 11 attack, it brought international issues into the lives of many people. Another potential link is the salience of an issue, how much a person feels that this issue directly affects them, and their trust in the government in this area. Hetherington and Husser found that the trust in the government in the area of defense correlates with more mentions of defense issues in their content analysis from 1980-2004. They found a similar correlation when looking at aid to blacks in terms of a similar content analysis looking for references to black issues instead of defense issues. A similar conclusion was found in the study by Robinson et al, where they examined the trust in specifically the Department of Homeland Security and not the government at large. They found that attention paid to terrorism and the DHS was correlated to giving the DHS a higher score for satisfaction.

It is worth noting that public opinion on investigation policies of the United States in general and the Patriot Act specifically has been difficult to fully understand. This is likely because of both secrecy on the part of the government in these policies and the perceived popularity behind them (Stoycheff 2016; Best and McDermott 2007; Sagar 2009). Sagar finds that the classified nature of these laws creates an asymmetry between what the public knows is being done and what the government is actually doing. This asymmetry allows for them to remove safeguards normally in these programs, making them broader and more invasive than they outwardly appear (Sagar 2009). This lack of information makes it more difficult to get 
correct information on people's opinions on an issue. Best and McDermott found that when there is insufficient information on a subject, the questions that are asked in surveys may have a greater effect in swaying people's responses. They found that when people were given a general description of the Patriot Act, they supported it at a rate of $62 \%$, as opposed to more narrow description of the act's provisions such as the ability to search home without notification at $40 \%$ and searches of records without notification at $53 \%$. In addition to the secrecy, there was a lack of willingness to go against the majority when voicing opinions on surveillance policy. Stoycheff (2016) found that when a person's opinion on surveillance policy was different from the perceived majority, they were less likely to voice this opinion when talking in online forums. She also found that people were not more likely to speak out against this surveillance even if they know that it is happening and they feel it is unjust. These factors make it difficult to fully understand what the actual public opinion on the use of these policies actually is.

This change in the public's opinion has several different explanations. One explanation for this is that in times where there is a security crisis a "center-right" consensus forms. Pantazis and Pemberton (2012) examined UK politics in the twenty-first century and found that twothirds of the British population were supportive of the new anti-terror laws passed by the conservative parliament and $73 \%$ said that it is right to lose some civil liberties in order to improve security. Another explanation links support for these policies with the levels of authoritarianism in individuals (Hetherington and Suhay 2011). Using a measure that Hetherington and Suhay (2011) developed from answers to questions such as "is it more important for children to have: 'Obedience vs. self-reliance', 'being considerate vs. being wellbehaved', etc." linking the ideals of have a well-ordered society with authoritarianism. This measure was checked against other measures on the survey such as support for warrantless 
wiretaps, support for media censorship, oppose criticizing the president, among other things. Hetherington and Suhay (2011) found that the authoritarian views correlated with the increased support for policies that reduce civil liberties.

Another explanation for this shift in public opinion is that there has been a shift in the views on civil liberties in general when it comes to criminals. Terrorism is one of several serious crimes which is being considered for this exception and does not have a specific exemption for civil liberties of the accused (Mondak and Hurwitz 2012). When it comes to terrorism: $35.7 \%$ of people favor or strongly favor removing the need for warrants for searches of suspects homes, $46.7 \%$ favor or strongly favor compelling testimony, and $33.8 \%$ of people favor or strongly favor indefinite pre-trial detention for suspects. This compared to people's views on serious crimes: $28.2 \%$ of people favor or strongly favor removing the need for warrants for searches of suspects homes, $36 \%$ favor or strongly favor compelling testimony, and $26.3 \%$ of people favor or strongly favor indefinite pre-trial detention for suspects (Mondak and Hurwitz 2012). Mondak and Hurwitz found that for two-thirds of people who support civil liberty exemptions for terrorist suspects, this is not an exclusive view about terrorism, but is actually their view on how suspects of serious crimes in general should be handled.

Many of the policies and increased policing that have gone on in the wake of the September 11 attack have been perceived by people of Arab American and Muslim communities to be targeting these groups (Sun, Wu, and Poteyeva 2011; Cherney and Murphy 2013). Sun, Wu and Poteyeva examined the opinions in the Arab American community of the programs used to combat terrorism. They found that Arab Americans had a low level of support for police programs, $52 \%$ were in favor of surveillance of the general public, $23 \%$ were in favor of allowing police to stop and search members of the general public, and 19\% were in favor of 
detaining someone who seemed suspicious even if there was no actual evidence; they also asked these same questions if these programs were targeted against Arab Americans and the percentage of those in favor dropped to $15 \%$ for surveillance, $7 \%$ for stop and search and $12 \%$ for detaining someone suspicious. Additionally, both Sun et al, and Cherney and Murphy found that there is a strong correlation between support for these laws in Arab American communities and the perceived legitimacy of the laws and the law enforcement.

This shifting view of civil liberties that affect privacy concerns may be shifting as a result of changing societal norms. Swigger (2013) examines how the rise of social media platforms contributes to shifting views on certain civil liberties. He examines how social media may have shifted the views on both privacy concerns as well as free speech concerns as he hypothesizes that these platforms put high value on expression over privacy. Swigger separates out respondents by age; under 25, and 25 and over; and uses this as a measure of people who have learned socialization skills in the age of the internet and social media. Swigger does find that there is a strong correlation $(\mathrm{p}<.05)$ for lack of support for privacy and for support of freedom of speech. Swigger notes that this shift could be caused by other factors as it is not an exact measure of social media socialization, but it is evident that there is a shift in these views based on age.

The regards for civil liberties also cut across ideological and racial dividing lines. Davis and Silver (2004) examine how political ideology and race affect people's views on civil liberties when they are concerned about another terror attack. The general trend is that when people are less concerned about a terrorist attack, they are more pro-civil liberties. This breaks out even further as people who are liberal tend to be more concerned for civil liberties at all levels of concern than conservatives, usually at about a 9 percentage-point difference (No concern about 
an attack:78\% pro-civ. lib. among liberals and 69\% pro-civ. lib. among conservatives. Very concerned: for liberals and $45 \%$ for conservative). Additionally, among different racial groups there is also a difference in concern. Davis and Silver found that overall African Americans are the most concerned about civil liberties and that Latinos and Whites concerns over civil liberties reach a similar percentage as concern over an attack gets higher (not at all concerned: $74 \%$ for African Americans, 72\% for Latinos, and 63\% for Whites. Very concerned: 64\% for African Americans, and $48 \%$ for both Latinos and Whites).

In order to gain more information on terrorist attacks and terrorist activities, the United States government would employ tactics known as enhanced interrogation techniques, some of which included torture (Liberman 2014). Gronke et al (2010) find that support for torture did not reach favorable levels until 2009 and not at all for some of the harsher techniques. Gronke et al shows that it was not until April 2009 that people who favored torture outnumbered those who opposed it (49\% favored, $47 \%$ opposed) and this number kept growing until the end of the studies' numbers in November of 2009. Additionally, Gronke et al explains why there is often a misconception of how many people actually support torture. They explain that people have a tendency to overestimate their own viewpoint on torture, the more they support it. They found that people who say torture is often justified, who make up $15 \%$ of the population, on average say that about a third of the population agrees with them; people who say that torture is sometimes justified, $30 \%$ of people, on average say that about $62 \%$ agree with their position, and people who are opposed to torture tend to have a good gauge of where people actually stand on the issue. Another interesting note in Gronke et al is that in a survey conducted in 2006 among Marine and Army soldiers, they were overall opposed to torture, even if it will save the life of a fellow soldier ( $56 \%$ oppose in the marines, $59 \%$ oppose in the army). 


\section{Methods}

This study uses General Social Survey (GSS) data from 2016 to see if these correlation between these data points. I use SPSS to run the analyses on the data in this study. The main data points that are used deal with the government using certain powers when going after terrorist suspects. The question asked in the GSS is: "suppose the government suspected a terrorist act was about to happen. Do you think the authorities should have the right to: detain people for as long as they want without putting them on trial (wotrial), tap people's phone conversations (tapphone), and stop and search people in the street at random (stoprndm)?" Additionally, I use data aimed at seeing people's opinions about whether the government should have the ability to surveil citizens in their everyday lives. The variables that are used for this are: "Do you think that the American government should or should not have the right to do the following? Monitor emails and any other information exchanged on the Internet? (emonitor), keep people under video surveillance in public areas? (cctv), collect information about anyone living in America without their knowledge? (givinfusa), and collect information about anyone living in other countries without their knowledge? (givinffor)". These dependent variables will illustrate public opinion about whether the government should have the power to conduct blanket surveillance of citizens and if the government should be able to use increased power to pursue terrorist suspects.

These variables will be run firstly against descriptive variables such as respondent's age (age); respondent's race (race), defined by a self-report of white, black, and other; respondent's sex (sex), defined as a self-report of male and female; and respondent's degree (degree), defined by the respondent's highest degree earned. These variables represent general demographic data 
and running a linear regression with these variables and the dependent variables is a good place to get a basic understanding of who may support these polices.

After doing this analysis I examine the dependent variables by running a regression of different independent variables. The first of these variables is aimed at people's political ideologies. The question in the GSS data is: "I am going to show you a seven-point scale on which the political views that people might hold are arranged from extremely liberal--point 1--to extremely conservative--point 7. Where would you place yourself on this scale? (polviews). This will show if these opinions trend with a certain political ideology."

The next variables run are meant to see if people have confidence in the various federal institutions who would have a role to play in going after terrorist suspects. This data is in the GSS as: I am going to name some institutions in this country. As far as the people running these institutions are concerned, would you say you have a great deal of confidence, only some confidence, or hardly any confidence at all in them? This question is asked about the following parts of the government: Executive branch of the federal government (confed), U.S. supreme court (conjudge), Congress (conlegis), and military (conarmy).

The final set variables I will run in this analysis is aimed at measuring people's trust in politicians and administrators. These variables are in the GSS as: How much do you agree or disagree with each of the following statements? People we elect to Congress try to keep the promises they have made during the election (poleff16), and Most government administrators can be trusted to do what is best for the country (poleff17).

The independent variables in this study look at people's political ideology, how much trust people have in the different branches of government, and how much trust they have in the people who run the government. These variables will give insight into whether political ideology 
and perception of government affect if Americans believe the government should use extra

powers against terrorist suspects.

Descriptive Statistics for the Variables

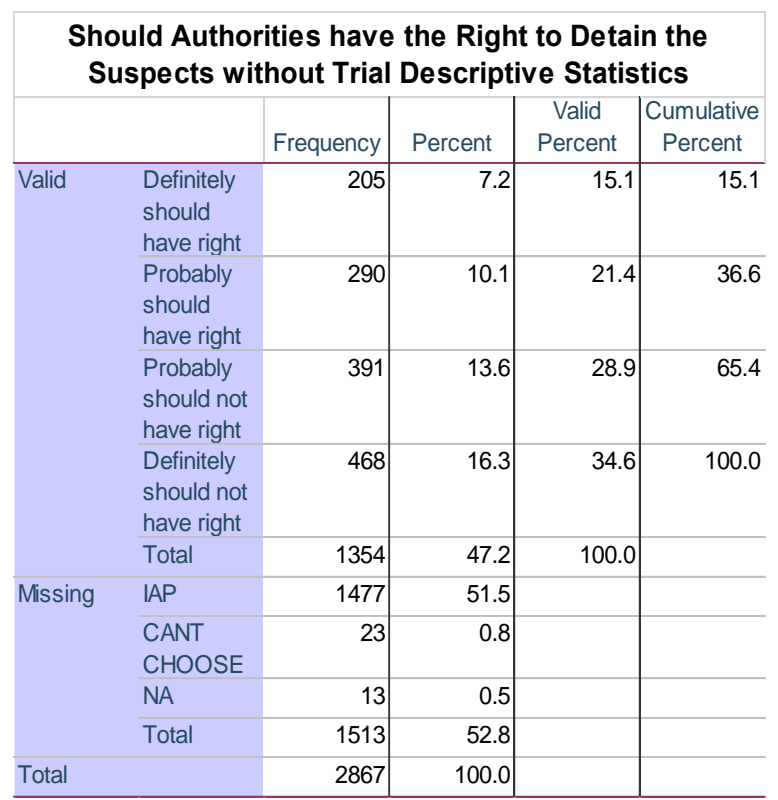

Should Authorities have the Right to Search People in the Street Descriptive Statistics

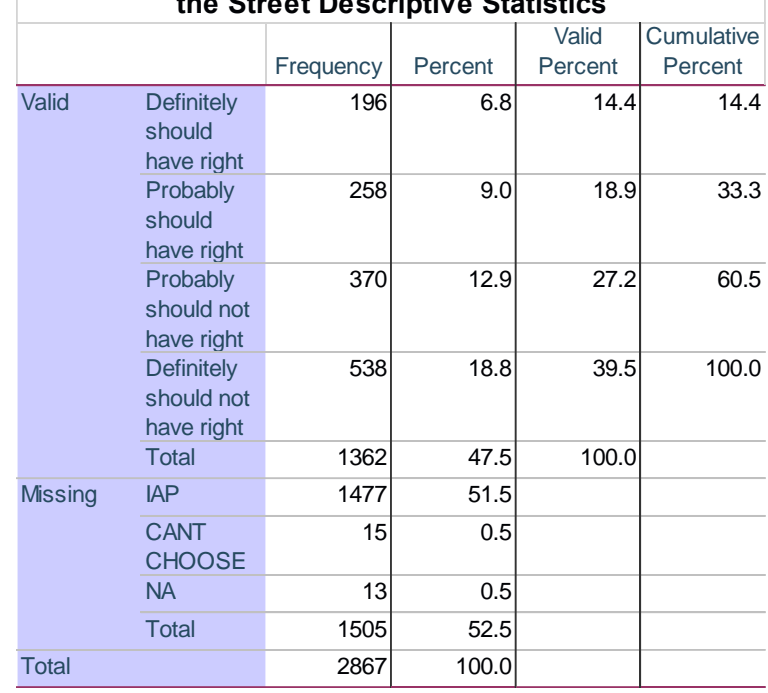

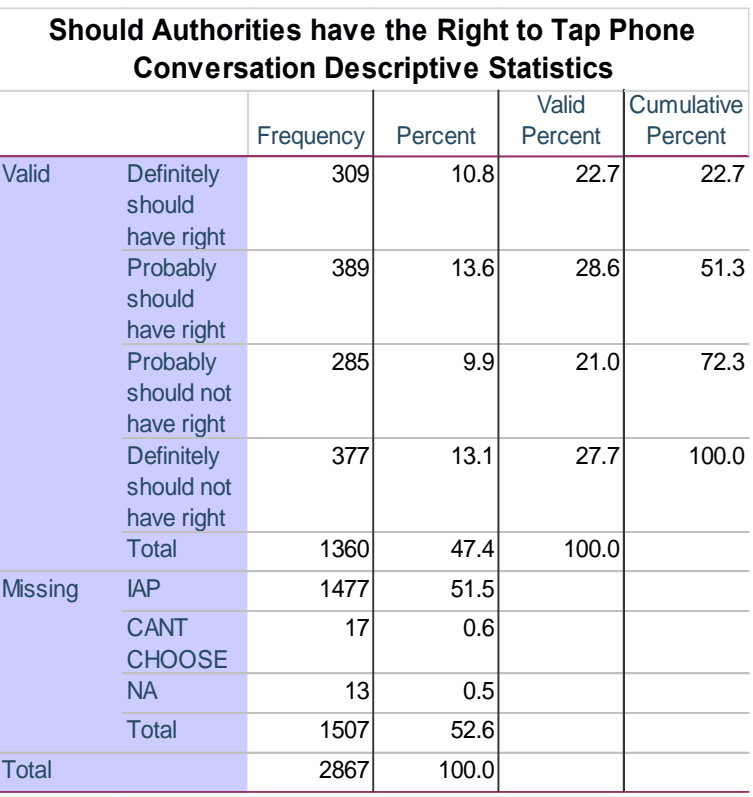

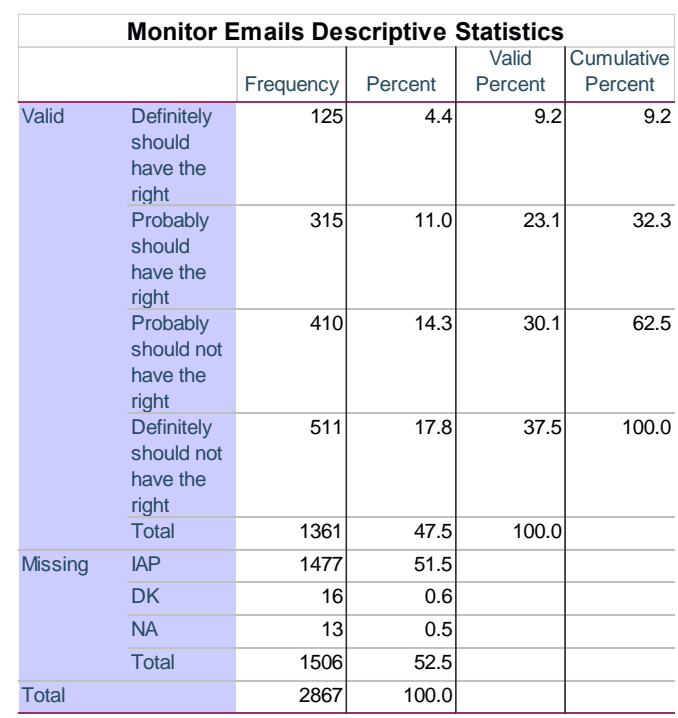




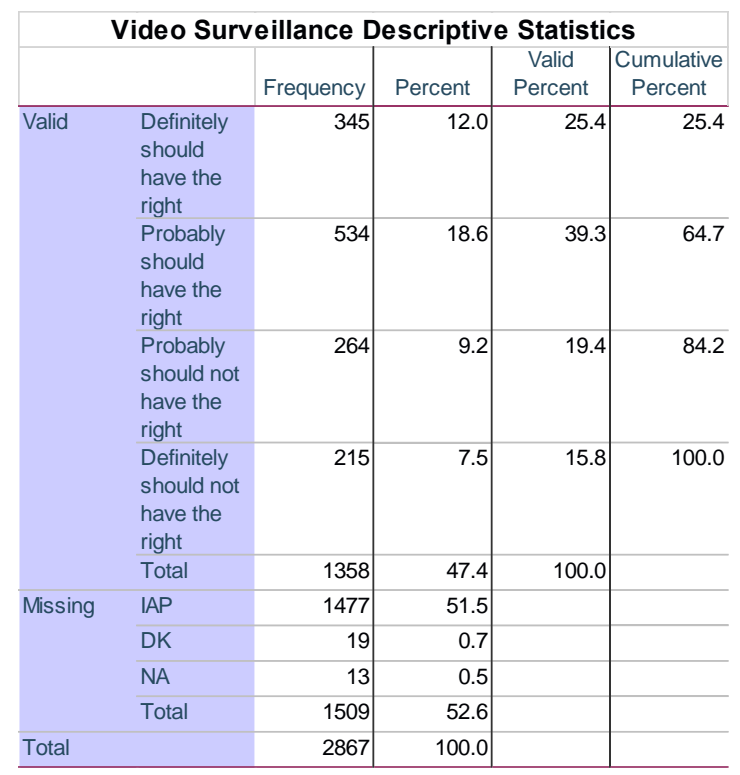

Should Government Collect Foreigner Info

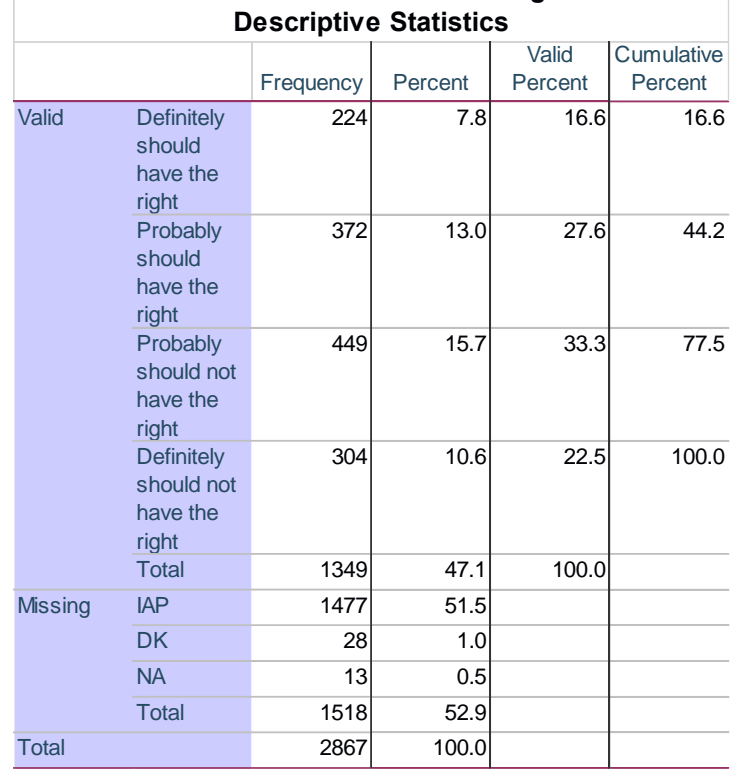

\begin{tabular}{|c|c|c|c|c|c|}
\hline \multicolumn{6}{|c|}{ Sex Descriptive Statistics } \\
\hline & & Frequency & Percent & $\begin{array}{c}\text { Valid } \\
\text { Percent }\end{array}$ & $\begin{array}{c}\text { Cumulative } \\
\text { Percent }\end{array}$ \\
\hline \multirow[t]{3}{*}{ Valid } & MALE & 1276 & 44.5 & 44.5 & 44.5 \\
\hline & FEMALE & 1591 & 55.5 & 55.5 & 100.0 \\
\hline & Total & 2867 & 100.0 & 100.0 & \\
\hline
\end{tabular}

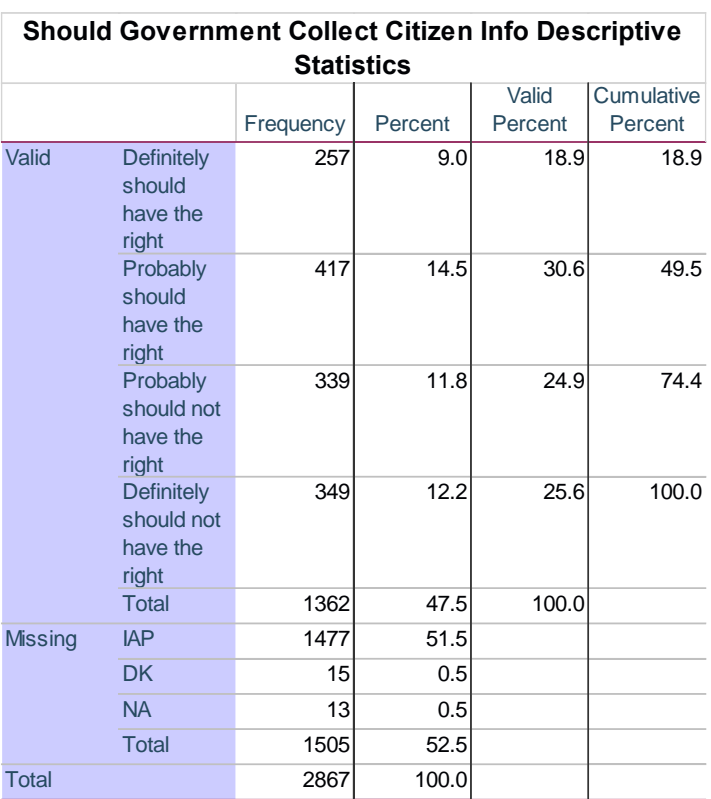

\begin{tabular}{|ll|r|r|r|r|}
\hline \multicolumn{6}{|c|}{ Age Descriptive Statistics } \\
\hline & & Frequency & Percent & $\begin{array}{c}\text { Valid } \\
\text { Percent }\end{array}$ & $\begin{array}{c}\text { Cumulative } \\
\text { Percent }\end{array}$ \\
\hline Valid & $18-24$ & 227 & 7.9 & 7.9 & 7.9 \\
\hline & $25-34$ & 510 & 17.8 & 17.9 & 25.8 \\
\hline & $35-44$ & 481 & 16.8 & 16.8 & 42.6 \\
\hline & $45-54$ & 489 & 17.1 & 17.1 & 59.7 \\
\hline & $55-64$ & 533 & 18.6 & 18.7 & 78.4 \\
\hline & $65-74$ & 356 & 12.4 & 12.5 & 90.9 \\
\hline \multirow{4}{*}{ Missing } & 75 and up & 261 & 9.1 & 9.1 & 100.0 \\
\hline Total & Total & 2857 & 99.7 & 100.0 & \\
\hline
\end{tabular}

\begin{tabular}{|c|c|c|c|c|c|}
\hline \multicolumn{6}{|c|}{ Race Descriptive Statistics } \\
\hline & & Frequency & Percent & $\begin{array}{l}\text { Valid } \\
\text { Percent }\end{array}$ & $\begin{array}{c}\text { Cumulative } \\
\text { Percent }\end{array}$ \\
\hline \multirow[t]{4}{*}{ Valid } & WHITE & 2100 & 73.2 & 73.2 & 73.2 \\
\hline & BLACK & 490 & 17.1 & 17.1 & 90.3 \\
\hline & OTHER & 277 & 9.7 & 9.7 & 100.0 \\
\hline & Total & 2867 & 100.0 & 100.0 & \\
\hline
\end{tabular}

\begin{tabular}{|c|c|c|c|c|c|}
\hline \multicolumn{6}{|c|}{ Degree Descriptive Statistics } \\
\hline & & Frequency & Percent & $\begin{array}{l}\text { Valid } \\
\text { Percent }\end{array}$ & $\begin{array}{c}\text { Cumulative } \\
\text { Percent }\end{array}$ \\
\hline \multirow[t]{6}{*}{ Valid } & $\begin{array}{l}\text { LT HIGH } \\
\text { SCHOOL }\end{array}$ & 328 & 11.4 & 11.5 & 11.5 \\
\hline & & 1461 & 51.0 & 51.1 & 62.6 \\
\hline & $\begin{array}{l}\text { JUNIOR } \\
\text { COLLEGE }\end{array}$ & 216 & 7.5 & 7.6 & 70.1 \\
\hline & $\begin{array}{l}\text { BACHELO } \\
\mathrm{R}\end{array}$ & 536 & 18.7 & 18.7 & 88.9 \\
\hline & $\begin{array}{l}\text { GRADUAT } \\
\mathrm{E}\end{array}$ & 318 & 11.1 & 11.1 & 100.0 \\
\hline & Total & 2859 & 99.7 & 100.0 & \\
\hline Missing & NA & 8 & 0.3 & & \\
\hline Total & & 2867 & 100.0 & & \\
\hline
\end{tabular}




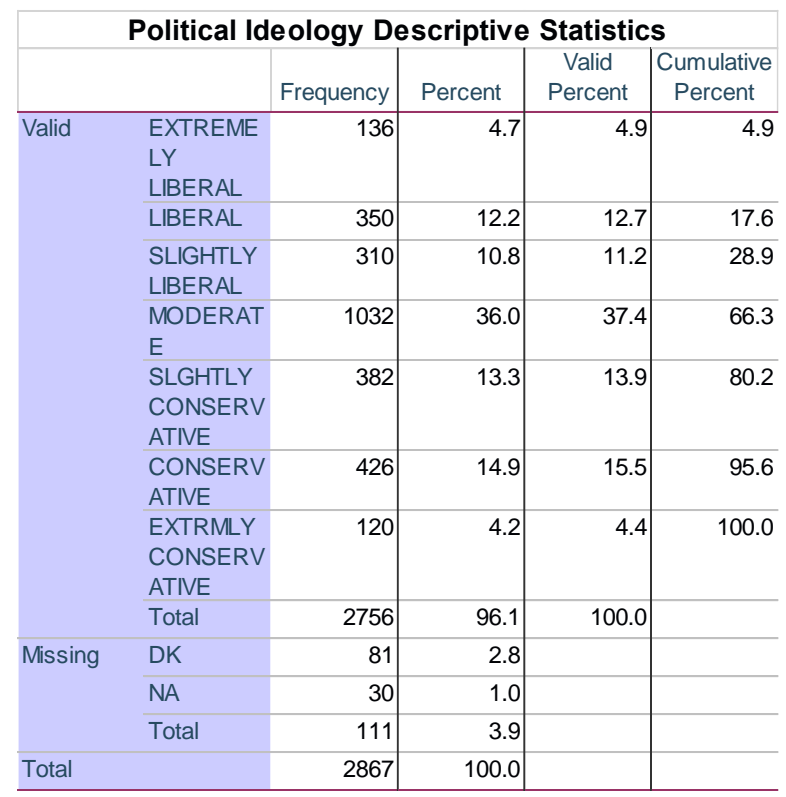

\begin{tabular}{|c|c|c|c|c|c|}
\hline \multicolumn{6}{|c|}{ Confidence in Supreme Court Descriptive Statistics } \\
\hline & & Frequency & Percent & $\begin{array}{l}\text { Valid } \\
\text { Percent }\end{array}$ & $\begin{array}{c}\text { Cumulative } \\
\text { Percent }\end{array}$ \\
\hline \multirow[t]{4}{*}{ Valid } & $\begin{array}{l}\text { A GREAT } \\
\text { DEAL }\end{array}$ & 488 & 17.0 & 25.5 & 25.5 \\
\hline & $\begin{array}{l}\text { ONLY } \\
\text { SOME }\end{array}$ & 1038 & 36.2 & 54.2 & 79.7 \\
\hline & $\begin{array}{l}\text { HARDLY } \\
\text { ANY }\end{array}$ & 389 & 13.6 & 20.3 & 100.0 \\
\hline & Total & 1915 & 66.8 & 100.0 & \\
\hline \multirow[t]{4}{*}{ Missing } & IAP & 911 & 31.8 & & \\
\hline & DK & 37 & 1.3 & & \\
\hline & NA & 4 & 0.1 & & \\
\hline & Total & 952 & 33.2 & & \\
\hline Total & & 2867 & 100.0 & & \\
\hline
\end{tabular}

\begin{tabular}{|c|c|c|c|c|c|}
\hline \multicolumn{6}{|c|}{ Confidence in Military Descriptive Statistics } \\
\hline & & Frequency & Percent & $\begin{array}{l}\text { Valid } \\
\text { Percent }\end{array}$ & $\begin{array}{c}\text { Cumulative } \\
\text { Percent }\end{array}$ \\
\hline \multirow[t]{4}{*}{ Valid } & $\begin{array}{l}\text { A GREAT } \\
\text { DEAL }\end{array}$ & 1027 & 35.8 & 53.0 & 53.0 \\
\hline & $\begin{array}{l}\text { ONLY } \\
\text { SOME }\end{array}$ & 763 & 26.6 & 39.4 & 92.4 \\
\hline & $\begin{array}{l}\text { HARDLY } \\
\text { ANY }\end{array}$ & 147 & 5.1 & 7.6 & 100.0 \\
\hline & Total & 1937 & 67.6 & 100.0 & \\
\hline \multirow[t]{4}{*}{ Missing } & IAP & 911 & 31.8 & & \\
\hline & DK & 16 & 0.6 & & \\
\hline & NA & 3 & 0.1 & & \\
\hline & Total & 930 & 32.4 & & \\
\hline Total & & 2867 & 100.0 & & \\
\hline
\end{tabular}

\section{Confidence in Executive Branch Descriptive Statistics}

\begin{tabular}{ll|r|r|r|r}
\hline & Frequency & Percent & $\begin{array}{c}\text { Valid } \\
\text { Percent }\end{array}$ & $\begin{array}{c}\text { Cumulative } \\
\text { Percent }\end{array}$ \\
\hline Valid & A GREAT & 238 & 8.3 & 12.4 & 12.4 \\
& DEAL & & & & \\
& ONLY & 851 & 29.7 & 44.4 & 56.8 \\
& SOME & & & & \\
& HARDLY & 827 & 28.8 & 43.2 & 100.0 \\
& ANY & 1916 & 66.8 & 100.0 & \\
& Total & 911 & 31.8 & & \\
\hline \multirow{5}{*}{ Missing } & IAP & 36 & 1.3 & & \\
& DK & 4 & 0.1 & & \\
& NA & 951 & 33.2 & & \\
& Total & 2867 & 100.0 & & \\
\hline \multirow{5}{*}{ Total } & & & & & \\
\hline
\end{tabular}

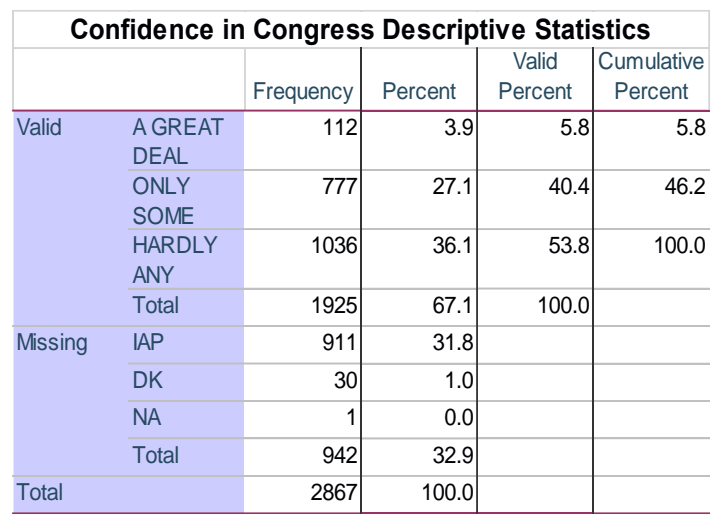

\begin{tabular}{|c|c|c|c|c|c|}
\hline \multicolumn{6}{|c|}{$\begin{array}{c}\text { People Elected to Congress Try to Keep Promises } \\
\text { Descriptive Statistics }\end{array}$} \\
\hline & & Frequency & Percent & $\begin{array}{l}\text { Valid } \\
\text { Percent }\end{array}$ & $\begin{array}{c}\text { Cumulative } \\
\text { Percent }\end{array}$ \\
\hline \multirow[t]{6}{*}{ Valid } & $\begin{array}{l}\text { STRONGL } \\
\text { Y AGREE }\end{array}$ & 36 & 1.3 & 2.6 & 2.6 \\
\hline & AGREE & 247 & 8.6 & 18.1 & 20.7 \\
\hline & $\begin{array}{l}\text { NEITHER } \\
\text { AGREE } \\
\text { NOR } \\
\text { DISAGREE }\end{array}$ & 303 & 10.6 & 22.2 & 42.9 \\
\hline & DISAGREE & 540 & 18.8 & 39.5 & 82.4 \\
\hline & $\begin{array}{l}\text { STRONGL } \\
\text { Y } \\
\text { DISAGREE }\end{array}$ & 240 & 8.4 & 17.6 & 100.0 \\
\hline & Total & 1366 & 47.6 & 100.0 & \\
\hline \multirow[t]{4}{*}{ Missing } & IAP & 1477 & 51.5 & & \\
\hline & $\begin{array}{l}\text { CANT } \\
\text { CHOOSE }\end{array}$ & 12 & 0.4 & & \\
\hline & NA & 12 & 0.4 & & \\
\hline & Total & 1501 & 52.4 & & \\
\hline Total & & 2867 & 100.0 & & \\
\hline
\end{tabular}




\begin{tabular}{|c|c|c|c|c|c|}
\hline \multicolumn{6}{|c|}{$\begin{array}{c}\text { Most Government Administrators can be Trusted } \\
\text { Descriptive Statistics }\end{array}$} \\
\hline & & Frequency & Percent & $\begin{array}{l}\text { Valid } \\
\text { Percent }\end{array}$ & \begin{tabular}{|c} 
Cumulative \\
Percent
\end{tabular} \\
\hline \multirow[t]{6}{*}{ Valid } & $\begin{array}{l}\text { STRONGL } \\
\text { YAGREE }\end{array}$ & 22 & 0.8 & 1.6 & 1.6 \\
\hline & AGREE & 270 & 9.4 & 19.8 & 21.4 \\
\hline & $\begin{array}{l}\text { NEITHER } \\
\text { AGREE } \\
\text { NOR } \\
\text { DISAGREE }\end{array}$ & 394 & 13.7 & 28.8 & 50.2 \\
\hline & DISAGREE & 512 & 17.9 & 37.5 & 87.7 \\
\hline & $\begin{array}{l}\text { STRONGL } \\
\text { Y } \\
\text { DISAGREE }\end{array}$ & 168 & 5.9 & 12.3 & 100.0 \\
\hline & Total & 1366 & 47.6 & 100.0 & \\
\hline \multirow[t]{4}{*}{ Missing } & IAP & 1477 & 51.5 & & \\
\hline & $\begin{array}{l}\text { CANT } \\
\text { CHOOSE }\end{array}$ & 12 & 0.4 & & \\
\hline & NA & 12 & 0.4 & & \\
\hline & Total & 1501 & 52.4 & & \\
\hline Total & & 2867 & 100.0 & & \\
\hline
\end{tabular}

\section{General Social Survey}

The General Social Survey is a survey of adults conducted by the National Opinion Research Center at the University of Chicago. This survey consists of interviewers going out and interviewing people in different regions of the United States, in an effort to get a representative sample of the United States' population. The Survey consists of a number of core questions they ask every two years when it is conducted as well as questions selected for that particular round of surveys. Additionally, some of the questions in the survey are not asked of the whole group in order to streamline the questions that the interviewers need to ask but are separated evenly among different groups of those taking the survey. The survey is given to several thousand respondents so that the results can be generalized to the population at large. I opted to use this data set as it is a dataset that is good for generalizability in both the number of respondents and the regions of the country that it reaches. The GSS is a good way to examine people in the 
United States and the 2016 data set had several questions on police powers and trust that I wanted to examine further in this context.

\section{Limitations}

The major limitation of this study is the use of GSS Data for the analyses. This data was very useful to conduct the analysis but was still beholden to the data gathered by another service and forced to work within the constraints of the variables and categories that they had created. Additionally, due to the methodology of the way that this data is collected there were some variables that did not have many respondents, such as the one that measured if people trusted congresspeople to keep their promises, meant that when checked against the test variables there were not enough respondents in some answer categories to do proper analysis. Some of these variables (the ones examining peoples trust in government administrators and trust in members of congress to try to keep their promises) were collapsed in an effort to do the analysis, but in doing so some of the detail may have been lost. This lack of respondents in these variables may have also contributed to the lack of statistical significance in the variables measuring confidence.

\section{Findings}

Age

Table 1-Age and Powers

\begin{tabular}{|ccc|}
\hline Variable & Chi-Square & Sig $(\alpha=.05)$ \\
\hline STOPRNDM & 21.413 & 0.259 \\
\hline TAPPHONE & 43.402 & $0.001^{*}$ \\
\hline WOTRIAL & 19.609 & 0.355 \\
\hline CCTV & 23.216 & 0.182 \\
\hline EMONITOR & 27.898 & 0.064 \\
\hline
\end{tabular}




\begin{tabular}{|lll|}
\hline GIVINFUSA & 36.403 & $0.006^{*}$ \\
\hline GIVINFFOR & 81.206 & $0.000^{*}$ \\
\hline
\end{tabular}

When examining these variables in terms of the age of the respondents there is a general trend among respondents that the younger they are the higher the percentage of them believe the government should not have these powers, and the lower the percentage of people who believe the government definitely should not have these powers. This relationship seems to show that the powers being used by the government are less popular among people who are younger. This trend does not show that as people age, the percentage of them who believe that the government should or should not have these powers varies. These relationships may also be coincidental. The only variables that show statistical significance are should the government be allowed to tap a terrorist suspect's phone conversation and if the government should be allowed to collect info on United States citizens and foreigners without their knowledge. This may show that, with the exception of the youngest age block (18-24) that age is not an indicator of if people feels that the government should have these increased powers.

$\operatorname{Sex}$

Table 2-Sex and Powers

\begin{tabular}{|ccc|}
\hline Variable & Chi-Square & Sig $(\alpha=.05)$ \\
\hline STOPRNDM & 1.809 & 0.613 \\
\hline TAPPHONE & 0.334 & 0.954 \\
\hline WOTRIAL & 9.671 & $0.022^{*}$ \\
\hline CCTV & 12.880 & $0.005^{*}$ \\
\hline EMONITOR & 0.594 & 0.898 \\
\hline GIVINFUSA & 1.660 & 0.646 \\
\hline GIVINFFOR & 11.060 & $0.011^{*}$ \\
\hline
\end{tabular}


Several variables for sex show statistical significance, but these variables do not show a great variation in the numbers. For most of the variables the percentages are similar in terms of what powers they feel that the government should and should not have. The exceptions to this are the views on if the government should be allowed to detain suspects without a trial and if the government should be allowed to collect information on foreigners without the individual's knowledge. When it comes to detaining suspects without trial females tend to be more in favor of these policies, and males are more likely to be in favor of collecting data on foreigners. Both of these variables have statistical significance but conducting surveillance in public places also has some variance and statistical significance. This difference can be seen more so in how strongly the different sexes feel about these policies. More females feel that the government should definitely have this power than do males, however, more males feel the government should probably have these powers than do females. When both categories are taken together, they equal a similar percentage (64.8\% for males and $64.7 \%$ for females) are in favor of this policy. This may indicate that the only difference that exists between male and female respondents is generally the strength of their beliefs and not any difference in whether they agree or disagree.

\section{Race}

Table 3-Race and Powers

\begin{tabular}{ccc} 
Variable & Chi-Square & Sig $(\alpha=.05)$ \\
\hline STOPRNDM & 16.607 & $0.011^{*}$ \\
\hline TAPPHONE & 12.970 & $0.044^{*}$ \\
\hline WOTRIAL & 14.596 & $0.024^{*}$ \\
CCTV & 8.533 & 0.202 \\
\hline EMONITOR & 6.937 & 0.327 \\
\hline GIVINFUSA & 5.614 & 0.468 \\
\hline GIVINFFOR & 18.456 & $0.005^{*}$ \\
\hline
\end{tabular}


Race has an unexpected outcome to it. For the questions of if the government should be allowed to stop suspects on the street and search them, and if the government should be allowed to tap the phones of suspects; the data follows the anticipated trend where black people are less in favor of giving extra powers to the government that may infringe upon people's civil liberties. Black people are, however, more likely to support detaining suspects indefinitely without trial than white people, though a majority of both black and white people believe that the government either definitely should not or probably should not have this power. This policy is also unexpected for the "other" category for race as for this power given to the government there is a rise in support for detainment over the other policies. The "other" category for race has their highest percentage in this category in the people who definitely support this, and they have the closest thing to a majority who feel that the government should have this power (combined percentage of $48.5 \%$ who think that the government definitely should or probably should have this power). This category is difficult to analyze as it is a combination of all people who identify as neither black nor white, and so there is no way to know if this is a trend in a specific group or just a quirk of the subgroups that create this category. Another category that has statistical significance when examined using race is if the government should be allowed to collect information on foreigners without notifying them. Black people are more in favor of this kind of policy being in place when compared to the other categories on race. This may show that the priority for black people in defense of civil liberties may be things that affect them and so when it is collection of information of foreign citizens, they prioritize security since it is not their information that is being collected.

\section{Degree}


Table 4-Degree and Powers

\begin{tabular}{|ccc|}
\hline Variable & Chi-Square & Sig $(\alpha=.05)$ \\
\hline STOPRNDM & 19.032 & 0.088 \\
\hline TAPPHONE & 28.033 & $0.005^{*}$ \\
\hline WOTRIAL & 29.329 & $0.004^{*}$ \\
\hline CCTV & 25.352 & $0.013^{*}$ \\
\hline EMONITOR & 24.122 & $0.020^{*}$ \\
\hline GIVINFUSA & 19.671 & 0.074 \\
\hline GIVINFFOR & 39.453 & $0.000^{*}$ \\
\hline
\end{tabular}

The education level of respondents generally follows the trend of having people who are more educated being less in favor of these policies that expand the government's power. The largest jump in support seems to be between people who have less than a high school degree and people who have a high school degree or more. Another quirk of this data is that there tends to be a slight jump in support among people with bachelor's degrees when compared to people with junior college and graduate degrees. The one category where this does not seem to be the case is if the government should be allowed to conduct video surveillance in public places. When it comes to this policy, the opposite tends to be true where the percentage of people who support it goes up with levels of education of the respondent.

\section{Political Ideology}

Table 5-Political Ideology and Powers

\begin{tabular}{|ccc|}
\hline Variable & Chi-Square & Sig $(\alpha=.05)$ \\
\hline STOPRNDM & 24.074 & $0.001^{*}$ \\
\hline TAPPHONE & 7.099 & 0.312 \\
\hline WOTRIAL & 31.325 & $0.000^{*}$ \\
\hline CCTV & 1.198 & 0.977 \\
\hline EMONITOR & 14.707 & $0.023^{*}$ \\
\hline GIVINFUSA & 13.498 & $0.036^{*}$ \\
\hline GIVINFFOR & 17.015 & $0.009^{*}$ \\
\hline
\end{tabular}


In terms of respondent's political ideology, this variable behaved exactly as anticipated.

People who identified themselves as more liberal across all of the different variables were consistently less in favor of any of these measures. As well as people who identified as conservative tended to be those most in favor of these kinds of powers being granted to the government. It is also worthy of noting that the people who self-identified as moderate tended to be closer to the people who self-identified as conservative in the policies that they were asked about. This not only shows that conservative individuals are more in favor of these security policies, but also that when it comes to this issue, people who identify as centrists are closer to the conservative block. This may be why there was such support as people trended towards being in favor of these policies between the conservative and moderate blocks.

\section{Trust in Administrators and Congress to Keep Promises}

Table 6-Trust in Administrators and Powers

\begin{tabular}{ccc} 
Variable & Chi-Square & Sig $(\alpha=.05)$ \\
\hline STOPRNDM & 6.800 & 0.340 \\
\hline TAPPHONE & 15.813 & $0.015^{*}$ \\
\hline WOTRIAL & 31.554 & $0.035^{*}$ \\
\hline CCTV & 27.275 & $0.000^{*}$ \\
\hline EMONITOR & 22.313 & $0.001^{*}$ \\
\hline GIVINFUSA & 18.448 & $0.005^{*}$ \\
\hline GIVINFFOR & 4.184 & 0.652 \\
\hline
\end{tabular}

Table 7-Trust in Congress to Keep Promises and Powers

\begin{tabular}{|ccc|}
\hline Variable & Chi-Square & Sig $(\alpha=.05)$ \\
\hline STOPRNDM & 21.013 & $0.002^{*}$ \\
\hline TAPPHONE & 5.283 & 0.508 \\
\hline WOTRIAL & 6.425 & 0.377 \\
\hline CCTV & 9.263 & 0.159 \\
\hline EMONITOR & 12.207 & 0.058 \\
\hline GIVINFUSA & 18.037 & $0.006^{*}$ \\
\hline
\end{tabular}




GIVINFFOR $\quad 6.586 \quad 0.361$

The first two variables that are aimed at examining how people's trust in the government (that most government administrators can be trusted, and that people elected to congress try to keep their promises) effects the powers that the government should be given against terrorist suspects and for general surveillance followed a general trend without any outliers. This trend is that people who had trust in administrators and congress to keep their promise were more willing to grant these powers than did people who did not. Those who did not have an opinion on if they trusted government in these ways tended to fall in between support from those who agreed and disagreed, but there did not seem to be any trend to these points otherwise. This may be because they see the administrators as the ones who were enforcing the policy and so when people have trust in the administrators, they are more willing to support the policies.

\section{Confidence in Military}

Table 8-Confidence in Military and Powers

\begin{tabular}{|c|c|c|}
\hline Variable & Chi-Square & $\operatorname{Sig}(\alpha=.05)$ \\
\hline STOPRNDM & 17.961 & $0.006 *$ \\
\hline TAPPHONE & 22.533 & $0.001 *$ \\
\hline WOTRIAL & 27.235 & $0.000 *$ \\
\hline CCTV & 8.272 & 0.219 \\
\hline EMONITOR & 15.834 & $0.015^{*}$ \\
\hline GIVINFUSA & 28.864 & $0.000 *$ \\
\hline GIVINFFOR & 19.897 & $0.003 *$ \\
\hline
\end{tabular}

When it comes to how much confidence people have in the military, this data follows a similar trend to those examining trust in the government, with those with greater trust in the military believing that these powers should be granted to the government in a higher percentage than those without confidence in the military. One thing that is interesting is in the way these 
numbers go down as people's confidence in the military goes down for the questions on granting powers to pursue terrorist suspects specifically. Overall, there is less in the total for people who feel the government definitely should and probably should have these powers; but people with only some confidence in the military see a steep decline in the percentage for both of these variables. For people who have hardly any confidence in the military the decline continues in the category of probably should not have, however there is an increase in the number of people who believe the government definitely should have these powers. This steep decline is also not present when comparing confidence in the military to any of the other variables in this analysis. These other variables did follow the general trend that as the confidence in the military went down, the belief that the government should have these powers also went down. This is likely similar to the trust in administrators, people see the military as likely the ones enforcing some of these policies and so when people have more confidence in the military. This may also explain why the variables on powers to go after terrorist suspects specifically have the steepest decline, as these may be the power people associate with the military the most.

\section{Confidence in the Executive}

Table 9-Confidence in the Executive and

Powers

\begin{tabular}{|ccc|}
\hline Variable & Chi-Square & Sig $(\alpha=.05)$ \\
\hline STOPRNDM & 4.011 & 0.675 \\
\hline TAPPHONE & 2.249 & 0.895 \\
\hline WOTRIAL & 5.739 & 0.453 \\
\hline CCTV & 7.705 & 0.261 \\
\hline EMONITOR & 8.117 & 0.230 \\
\hline GIVINFUSA & 4.169 & 0.654 \\
\hline GIVINFFOR & 20.545 & $0.002 *$ \\
\hline
\end{tabular}


The analysis that examined confidence in the executive branch showed that with most of the variables, there is no significance between confidence in the executive and the variables examined. The exception to this is if the government should be allowed to collect information on foreigners. This data also does something unexpected where the overall percentage of people who believe that the government should have this power goes down from people with a great deal of confidence in the executive and people who have only some confidence in the executive. For people who have hardly any confidence in the executive, these percentages are higher than where they were for people who have a great deal of trust in the executive. This may show that people who do not have a strong opinion on the executive may not have a strong opinion when it comes to these policies as well.

\section{Confidence in Legislature}

Table 10-Confidence in the Legislature and

Powers

\begin{tabular}{|ccc|}
\hline Variable & Chi-Square & Sig $(\alpha=.05)$ \\
\hline STOPRNDM & 4.494 & 0.610 \\
\hline TAPPHONE & 10.003 & 0.125 \\
\hline WOTRIAL & 8.641 & 0.195 \\
\hline CCTV & 12.776 & $0.047^{*}$ \\
\hline EMONITOR & 4.796 & 0.570 \\
\hline GIVINFUSA & 9.042 & 0.171 \\
\hline GIVINFFOR & 18.630 & $0.005^{*}$ \\
\hline
\end{tabular}

When it comes to confidence in the legislature, it is very similar to the breakdown in confidence in the executive. The only variables with statistical significance are if the government should be allowed to collect information on foreigners and if the government should be allowed to conduct video surveillance in public areas. For the video surveillance variable, the only shift is in the number of respondents who say that the government definitely should and probably should 
have this power, the overall approval percentage remains the same. For the collection of information of foreigners, it follows the same trend as the executive where it dips between people with a great deal of confidence in the legislature and those with only some, and then raises to its highest level with those with hardly any confidence in the legislature. This may show that when it comes to gathering information on foreigners, the legislature is not the branch that people think are the ones in charge of this gathering and so they do not need to have confidence in them to be in support of this policy.

\section{Confidence in Supreme Court}

Table 11-Confidence in the Supreme Court and Powers

\begin{tabular}{|ccc|}
\hline Variable & Chi-Square & Sig $(\alpha=.05)$ \\
\hline STOPRNDM & 6.855 & 0.334 \\
\hline TAPPHONE & 5.552 & 0.475 \\
\hline WOTRIAL & 12.594 & $0.050^{*}$ \\
\hline CCTV & 10.363 & 0.110 \\
\hline EMONITOR & 17.164 & $0.009^{*}$ \\
\hline GIVINFUSA & 6.396 & 0.380 \\
\hline GIVINFFOR & 12.356 & 0.054 \\
\hline
\end{tabular}

When it comes to confidence in the supreme court in relation to these variables, there is once again a lack of significance for many of the variables. The only ones with significance are if the government should be allowed to monitor people's emails and if the government should have the right to detain suspects of terrorism without trial. (though this one is barely significant). In support for detaining people without trial, there is a steady rise in support for this power being given to the government as confidence in the supreme court goes down. The opposite is the case when it comes to if the government should have the ability to monitor people's emails, with the most support being with the people who have a great deal of confidence in the Supreme Court. 
The detaining variable having more significance as it goes down makes sense, as detaining suspects without trial is directly subverting the court system. It may be that people do not feel that the courts will give a verdict they agree with and so it is better to not involve them in that decision. The opposite trend being in place for the monitoring of emails may show more that people are more willing to allow this power when the courts have some oversight of this collection.

\section{Multiple Regressions}

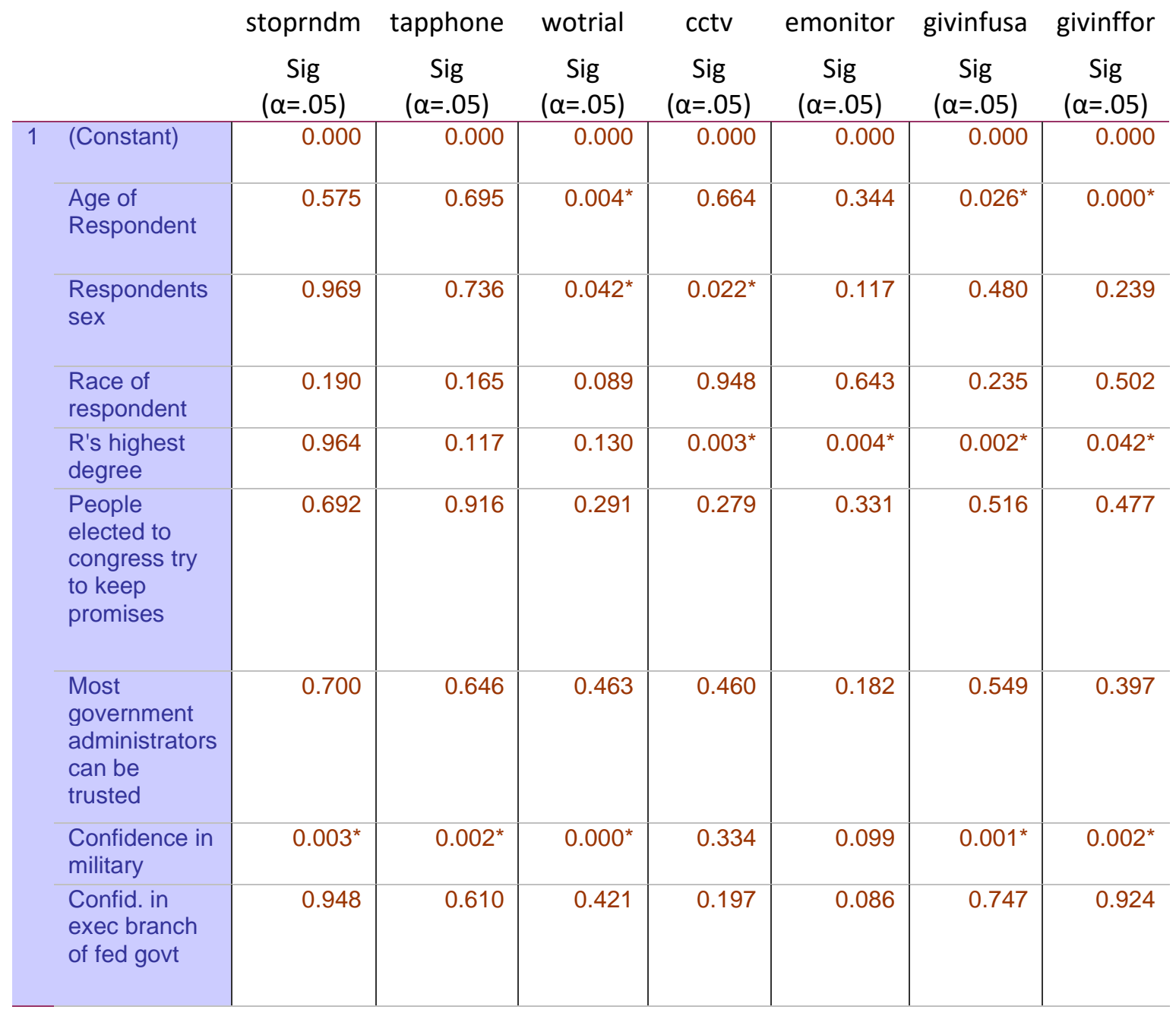




\begin{tabular}{l|r|r|r|r|r|r|r}
$\begin{array}{l}\text { Confid. in } \\
\text { united states } \\
\text { supreme } \\
\text { court }\end{array}$ & 0.523 & 0.399 & $0.036^{*}$ & 0.477 & 0.130 & 0.227 & 0.531 \\
\hline $\begin{array}{l}\text { Confidence in } \\
\text { congress }\end{array}$ & 0.902 & 0.229 & 0.181 & 0.123 & 0.958 & 0.619 & 0.978 \\
\hline $\begin{array}{l}\text { Think of self } \\
\text { as liberal or } \\
\text { conservative }\end{array}$ & 0.679 & 0.597 & 0.975 & 0.358 & 0.092 & 0.867 & 0.341 \\
\hline
\end{tabular}

When a multiple regression is run on each of the dependent variables using all of the independent variables, there are several independent variables that consistently appear. Confidence in the military is the most frequently significant of these variables, having significance in five of the seven dependent variables (Tables 12, 13, 14, 17 and 18). Additionally, for the variables of stoprndm (Table 12) and tapphone (Table 13) confidence in the military is the only variable with significance in the multiple regressions. The other independent variables that have multiple appearances of significance are age, degree, and sex. Age (Tables14, 17, and 18) and degree (Tables 15, 16, 17, and 18) have significance in three variables, respectively (wotrial, givinfusa, and givinffor for age; and cctv, emonitor, and givinfusa for degree), and sex had significance in two variables: wotrial (Table 14) and cctv (Table 15). The dependent variable that had the most independent variables with significance was wotrial (Table 14) that had four: age, sex, confidence in military, confidence in the Supreme Court.

\section{Discussion}

There are some conclusions that can be drawn from this examination that were unexpected. Firstly, based on the multiple regressions it seems as though political ideology may be a confounding variable for something else. Namely that confidence in the military seems to be one of the more important factors in determining support for these powers. One such explanation 
for this may be that many of the police powers would be employed by the military or militaryrelated organizations. This would mean that people who have more confidence in these organizations would be more willing to trust them with these powers. This may also explain why trust in other parts of the government lose their significance in the multiple regression. This may also help to explain why support for detaining someone without trial as people's trust in the Supreme Court goes down. People who have less trust in the courts may not see the necessity or legitimacy of trial anyway and so they believe that detaining without a trial is a power that should be granted to another part of the government.

The importance of degree may be linked to people having a greater understanding of some of the wider consequences of policies and this is reflected in their views on the powers that the government should be given. This may be why public camera surveillance becomes more popular with degree as it is less intrusive than the other variables it is significant within the multiple regression, monitoring people's emails and collecting info on American citizens. Age may be attributed to a belief in how serious these policies may be for the objectives they espouse. Younger respondents, especially those in the 18-24 range, may not have been as cognizant of the impacts of 9/11 at the time it occurred and see these policies and powers as less necessary as a result. For Sex, the significance in the cctv variables is more an indication of how strongly males and females feel about the issue. Males are more likely to think that the government definitely should have the right and probably should not have the right, and females are the inverse. But when definitely and probably should are combined, their percentages are virtually the same. The same is true for definitely should not and probably should not. For detaining suspects without a trial there is a numeric difference in views in addition to a statistical significance. In this, males 
are less likely to support this than females are. The prior research did not cover why this difference may be the case. Further research should be done to shed more light on this finding.

It should be addressed that political ideology loses its significance when the multiple regression is performed. This may be a sign that political ideology may actually be a confounding variable when examining why people believe these powers are necessary. That is to say that it may be that instead of being more conservative leading to an increase in support for these powers, it may just be that confidence in the military leads to being more conservative as well as believing that these powers were necessary.

\section{Conclusion}

These results show trends for the powers that people believe the government should have to pursue terror suspects and for general surveillance. There was not much significance for the variables that measure the confidence people had in the three main branches of the federal government when compared to if the government should employ these powers, and when there was significance some of the policies became more popular as confidence declined. This result was fairly unexpected and does not have a ready explanation that can be gleaned from the prior research. One possible explanation for this phenomenon may be that people may not see these parts of government as being directly responsible for administering these policies and therefore do not feel they need to have confidence in them for these policies to be put in place.

The analysis that focused on confidence in the military and trust in administrators and congresspeople tended to show more significance. This may be because they have more perceived importance when it comes to these policies as administrators and the military would be the ones likely tasked with carrying out these policies. The trend observed in the data examining 
people's political ideologies falls right in line with the trends observed in prior research, with more conservative respondents believing that these powers should be granted to the government more than liberal respondents.

The multiple regression revealed that political ideology may not be as important a variable in terms of peoples wanting to grant these powers to the government, and that other things such as confidence in the military and degree may be better indicators for what is significant in holding these beliefs. Future studies should examine more fully the relationship between support for these policies and confidence in the military. Other variables should be examined to see what else may hold significance when examined with support for these policies. Finally, it may be worthwhile to put the variables for confidence together and examine them together to see what would happen if the variables on confidence were indexed together. 


\section{References}

Abdolian, Lisa Finnegan, Harold Takooshian. 2003. "The usa patriot act: Civil liberties, the media, and public opinion" Fordham Urban Law Review 30(4): 1429-1454.

Avdan, Nazli, Clayton Webb. 2019. "Not in my Back Yard: Public Perceptions and Terrorism" Politica Research Quarterly 72(1) 90-103

Baker, John S., and Jonathan C. Fritts. 2012. "Competing paradigms of constitutional power in the war on terrorism" Notre Dame Journal of Law, Ethics and Public Policy 19(1): 5-31

Baker, Nancy V. 2003. "National Security versus Civil Liberties” Presidential Studies Quarterly 33 (3): $547-567$

Banks, Christopher. P., Steven Tauber. 2014. "U.S. district court decision-making in usa patriot act cases after september 11" Justice System Journal 35 (2): 139-161.

Barron, James. 2001 “Thousands Feared Dead as World Trade Center Is Toppled” New York Times, September $11^{\text {th }}, 2001$. Retrieved December $7^{\text {th }}, 2020$. (https://www.nytimes.com/2001/09/11/national/thousands-feared-dead-as-world-tradecenter-is-toppled.html?)

Best, Samuel J., Brian S. Krueger, and Jeffrey Ladewig. 2006. "Trends: Privacy in the Information Age" The Public Opinion Quarterly 70 (3): 375-401

Best, Samuel J., Monika L. McDermott. 2007. "Measuring Opinions vs. Non-Opinions - The Case of the USA PATRIOT Act" The Forum 5 (2) :1-27

Best, Samuel J., Brian S. Kruger. 2011. “Government Monitoring and Political Participation in the United States: The Distinct Roles of Anger and Anxiety” American Politics Research 39 (1): $85-117$ 
Braml, Josef. 2003. "Rule of law or dictates by fear: german perspective on American civil liberties in the war against terrorism”. Fletcher Forum of World Affairs 27 (2): 115-140.

Brewer, Paul R. 2004. "Public Trust in (Or Cynicism about) Other Nations across Time" Political Behavior 26 (4): 317-341

Brown, Ian, Douwe Korff. 2009. "Terrorism and the Proportionality of Internet Surveillance" European Journal of Criminology 6 (2): 119-134

Bush, George. 2001. 9/11 Address to the Nation

Chanley, Virginia A. 2002. "Trust in Government in the Aftermath of 9/11: Determinants and its consequences" Political Psychology 23(3): 469-483

Charkaoui v. Canada (Citizenship and Immigration), [2007] 1 S.C.R. 350, 2007 SCC 9

Chernry, Adrian, Kristina Murphy. 2013. "Policing Terrorism with Procedural Justice: The Role of Police Legitimacy in Law Legitimacy" Australian and New Zealand Journal of Criminology 46 (3): 403-421

Ciuk, David J. 2016. “Americans' Value Preferences Pre- and Post-9/11” Social Science Quarterly 97 (2): 407-417

Cole, Richard L., John Kincaid, Andrew Parkin. 2002. "Public Opinion on Federalism in the United States and Canada in 2002: The Aftermath of Terrorism" Publius 32 (4): 123-148

Conway, Mona. 2002. "Terrorism, the law and politics as usual: comparison of anti-terrorism legislation before and after 9/11. Touro Law Review” 18 (4): 735-782.

Davis, Darren W, and Brian D. Silver. 2004. "Civil Liberties vs. Security: Public Opinion in the Context of the Terrorist Attacks on America" American Journal of political Science 48(1):28-46 
De Londras, Fiona and Fergal F. Davis. 2010. "Controlling the Executive in Times of Terrorism: Competing Perspectives on Effective Oversight Mechanisms" Oxford Journal of Legal Studies 30 (1): 19-47

Deflem, Mathieu, Shannon McDonough. 2015. “The Fear of Counterterrorism Surveillance and Civil Liberties Since 9/11" Global Society 52: 70-79

Dinesen, Peter Thisted, Mads Meier Jaeger. 2013. The Effect of Terror of Institutional Trust: New Evidence from the 3/11 Madrid Terrorist Attack” Political Psychology 34 (6): 917926

Englund, Scott. 2015. “At What Cost? United States' Counter-Terrorism Strategy, Reputation, and Public Opinion”. Perspectives on Terrorism, 9(3), 39-55.

Findley, Michael G., Joseph K. Young. 2011. “Terrorism, Democracy, and Credible Commitments" International Studies Quarterly 55 (2): 357-378

Funk, William. 2007. "Electronic surveillance of terrorism: The intelligence/law enforcement dilemma a history" Lewis \& Clark Law Review 11(4): 1099-1140.

Gelev, Filip. 2011. "Checks and balances of risk management: precautionary logic and the judiciary" Review of International Studies 37 (5):2237-2252

Gould, Jon B. 2002. "Playing with Fire: The Civil Liberties Implications of September $11^{\text {th" }}$ Public Administration Review 62: 74-79

Gronke, Paul, Darius Rejali, Dustin Drenguis, James Hicks, Peter Miller, and Bryan Nakayama. 2010. “U.S. Public Opinion on Torture, 2001-2009” PS: Political Science and Politics 43 (3): $437-444$

Haggerty, Kevin D., Amber Gazso. 2005. "Seeing beyond the Ruins: Surveillance as a Response to Terrorist Threats" The Canadian Journal of Sociology 30(2): 169-187 
Haider-Markel, Donald P., Andre Vieux. 2008. "Gender and Conditional Support for Torture in the War on Terror" Politics \& Gender 4: 5-33

Hamdi v. Rumsfeld, 542 U.S. 507 (2004)

Haque, M. Shamsul. 2002. "Government Responses to Terrorism: Critical Views of Their Impacts on People and Public Administration” Public Administration Review 62: 170-180

Hardin, Russel. 2004. "Civil Liberties in the Era of Mass Terrorism” The Journal of Ethics 8 (1): $77-95$

Hempel, Leone, Eric Topfor. 2009. “The Surveillance Consensus: Reviewing the Politics of CCTV in Three European Countries" European Journal of Criminology 6 (2): 157-177

Henderson, Nathan C. 2002. "The patriot act's impact on the governments' ability to conduct electronic surveillance of ongoing domestic communications" Duke Law Journal 52 (1): $179-210$.

Hetherington, Marc J., Elizabeth Suhay. 2011. “Authoritarianism, Threat, and Americans' Support for the War on Terror” American Journal of Political Science 55 (3): 546-560

Hetherington, Marc J., Jason A. Husser. 2012. "How Trust Matters: The Changing Political Relevance of Political Trust” American Journal of Political Science 56 (2):312-325

Heymann, Philip B. 2002. "Civil Liberties and Human Rights in the Aftermath of September 11" Human Rights 29 (1): pp. 18-19

Huddy, Leonie, Nadia Khatib and Theresa Capelos. 2002. "Trends: Reactions to the Terrorist Attacks of September 11, 2001” The Public Opinion Quarterly 66 (3): 418-450

Huddy, Leonie, Stanley Feldman, Christopher Weber. 2007. “The Political Consequences of Perceived Threat and Felt Insecurity" The Annals of the American Academy 614: 131-153 
Huddy, Leone, Stanley Feldman, Charles Taber and Gallya Lahav. 2005. “Threat, Anxiety, and Support of Antiterrorism Policies” American Journal of Political Science 49 (3): 593-608 Hursh, John. 2012. Responses to the five questions. William Mitchell Law Review 38 (5): 15491563.

Johnson, Douglas A, Alberto Mora, and Averell Schmidt. 2016. "The Strategic Costs of Torture: How 'Enhanced Interrogation’ Hurt America” Foreign Affairs. September/October 2016. Retrieved December 7, 2020. (https://www.foreignaffairs.com/articles/unitedstates/strategic-costs-torture)

Johnson, Elizabeth. 2010. "Surveillance and privacy under the Obama administration: The foreign intelligence surveillance act of 1978 amendments act of 2008 and the attorney general's guidelines for domestic FBI operations" Journal of Law and Policy for the Information Society 5(3): 419-446.

Khan, Chris. 2016. "Exclusive: Most Americans support torture against terror suspects Reuters/Ipsos poll” Reuters, March 30, 2016. Retrieved December 7, 2020. (https://www.reuters.com/article/us-usa-election-torture-exclusive/exclusive-mostamericans-support-torture-against-terror-suspects-reuters-ipsos-pollidUSKCNOWWOY3)

Krueger, Alan B., Jitka Maleckova. 2009. "Attitudes and Action: Public Opinion and the Occurrence of International Terrorism”Science 325 (5947): 1534-1536

Lewis, Carol W. 2000. "The Terror That Failed: Public Opinion in the Aftermath of the Bombing in Oklahoma City" Public Administration Review 60 (3): 201-210

Lewis, Carol. 2005. "The Clash between Security and Liberty in the U.S. Response to Terror" Public Administration Review, 65(1): 18-30. 
Liberman, Peter. 2014. "War and Torture as 'Just Deserts"” The Public Opinion Quarterly 78 (1): $47-70$

Lobel, Jules. 2002. "The war on terrorism and civil liberties" University of Pittsburgh Law Review 63 (4): 767-790.

Lyte, Brittany. 2014. “Americans Have Grown More Supportive of Torture” FiveThirtyEight, December 9, 2014. Retrieved December 7, 2020. (https://fivethirtyeight.com/features/senate-torture-report-public-opinion/)

McArdle, Shelly C., Heather Rosoff, Richard John. 2012. "The Dynamics of Evolving Beliefs, Concerns Emotions, and Behavioral Avoidance Following 9/11: A Longitudinal Analysis of Representative Archival Samples” Risk Analysis 32 (4): 744-761

Miller, Steven. 2017. "The Effect of Terrorism on Judicial Confidence” Political Research Quarterly 70(4): 790-802.

Mondak, Jeffery J., Jon Hurtz. 2012. "Examining the Terror Exception: Terrorism and Commitments to Civil Liberty" Public Opinion Quarterly 76 (2): 193-213

Nakhaie, Reza, William de Lint. 2013. “Trust and Support for Surveillance in Canadian and American Opinion” International Criminal Justice Review 23 (2): 149-169

O’Coin, Chris. 2012. “'It's Too Quiet' The Early Morning Television of 9/11/2001” You-Tube Web Site. Retrieved December 7, 2020. (https://www.youtube.com/watch?v=IMVTB2aVUg0)

Ojeda, Christopher. 2016. "The Effect of 9/11 on the Heritability of Political Trust" Political Psychology 37 (1): 73-88 
Papacharissi, Zizi, Maria de Fatima Oliveira. 2008. "News Frames Terrorism: A Comparative Analysis of Frames Employed in Terrorism Coverage in U.S. and U.K. Newspapers” Press/Politics 13 (1): 52-74

Pantazis, Christina, Simon Pemberton. 2012. "Reconfiguring Security and Liberty: Political Discourse and Public Opinion in the New Century" The British Journal of Criminology 52(3): 651-667

Peterson, Karen K. 2009. “Revisiting Downs’ Issue-Attention Cycle: International Terrorism and U.S. Public Opinion” Journal of Strategic Security 2 (4): 1-16

Philipose, Liz. "The Politics of Pain and Uses of Torture” Signs 32 (4): 1047-1071

Pikowsky, Robert A. 2002. "An overview of the law of electronic surveillance post september 11, 2001” Law Library Journal, 94(4), 601-620.

Podgor, Ellen S, John Wesley Hall. 2003. "Government surveillance of attorney-client communications: Invoked in the name of fighting terrorism” Georgetown Journal of Legal Ethics 17 (1): 145-164.

Poznyak, Dmitriy, Bart Meuleman, Koen Abts and George F. Bishop. 2014. "Trust in American Government: Longitudinal Measurement Equivalence in the ANES, 1964-2008” Social Indicators Research 118 (2): 741-758

Priks, Mikael. 2014. "Do Surveillance Cameras Affect Unruly Behavior? A Close Look at Grandstands" the Scandinavian Journal of Economics 116 (4): 1160-1179

Rasul v. Bush, 542 U.S. 466 (2004)

Robinson, Scott E., Xinsheng Liu, James W. Stoutenborough, and Arnold Vedlitz. 2013. "Explaining Popular Trust in the Department of Homeland Security" Journal of Public Administration Research and Theory 23(3) :713-733 
Sagar, Rahul. 2009. "Who Holds the Balance? A Missing Detail in the Debate over Balancing Security and Liberty" Polity 41 (2): 166-188

Savage, Charlie. 2018. "I've Been Covering the Detention of Terrorism Suspects for 15 Years. What Have We Learned?” New York Times, July 26, 2018. Retrieved December 7, 2020. (https://www.nytimes.com/2018/07/26/insider/guantanamo-syria-terrorism-detaineesprisons.html)

Scott, Jeramie D. 2017. "Social media and government surveillance: The case for better privacy protections for our newest public space” Journal of Business and Technology Law 12 (2): 151-164.

Shane, Scott. 2007. “C.I.A. Agents Sense Shifting Support for Methods” New York Times, December 13, 2007. Retrieved December 7, 2020. (https://www.nytimes.com/2007/12/13/washington/13inquire.html)

Shaw, Greg M., Robert Y. Shapiro, Shmuel Lock and Lawrence R. Jacobs. 1998. “Trends: Crime, the Police, and Civil Liberties” The Public Opinion Quarterly 62 (3): 405-426

Shortell, Christopher, Charles Anthony Smith. 2005. "The institutional stability of the judiciary in the aftermath of terrorism" Judicature 88(4): 172-177.

Simone, Maria A. 2009. "Give me liberty and give me surveillance: a case study of the US government's discourse of surveillance" Critical Discourse Studies 6(1): 1-14

Smiley, Jodie et al. 2016. “General Social Survey” Research Highlights

Stettler, Brian. 2009. "How '07 ABC Interview Tilted a Torture Debate” New York Times, April 27, 2009. Retrieved December 7, 2020. (https://www.nytimes.com/2009/04/28/business/media/28abc.html) 
Stoycheff, Elizabeth. 2016. “Under Surveillance: Examining Facebook’s Spiral of Silence Effects in the Wake of NSA Internet Monitoring” Journalism \& Mass Communication Quarterly 93(2): 296-311

Sun, Ivan Y., Yunning Wu, and Margarita Poteyeva. 2001. “Arab Americans' Opinion on Counterterrorism Measures: The Impact of Race, Ethnicity, and Religion” Studies in Conflict \& Terrorism 34: 540-555

Swigger, Nathaniel. 2013. “The Online Citizen: Is Social Media Changing Citizens’ Beliefs About Democratic Values?” Political Behavior 35 (3): 589-603

Tyson, Alec. 2017. "Americans divided in views of use of torture in U.S. anti-terror efforts" Fact Tank, January 26, 2017. Retrieved December 7, 2020. (https://www.pewresearch.org/fact-tank/2017/01/26/americans-divided-in-views-of-useof-torture-in-u-s-anti-terror-efforts/)

Ullrich, Johannes, J. Christopher Cohrs. 2007. “Terrorism Salience increases System Justification: Experimental Evidence” Social Justice Research 20 (2): 117-139

USA PATRIOT Act, 115 Stat. 272 (2001)

Whitaker, Beth Elise. 2007. 'Exporting the Patriot Act? Democracy and the 'War on Terror' in the Third World" Third World Quarterly 28 (5): 1017-1032

Yagoda, Jay A. 2010. "Seeing is believing: The detainee abuse photos and open government's enduring resistance to their release during an age of terror" University of Florida Journal of Law and Public Policy 21 (2): 273-306.

Zilang, Yang. 2007. "Preventive Detention as Counter-Terrorism Strategy: They Have Stopped Using It and So Should We" Singapore Law Review 25: 24-34. 


\section{Appendix}

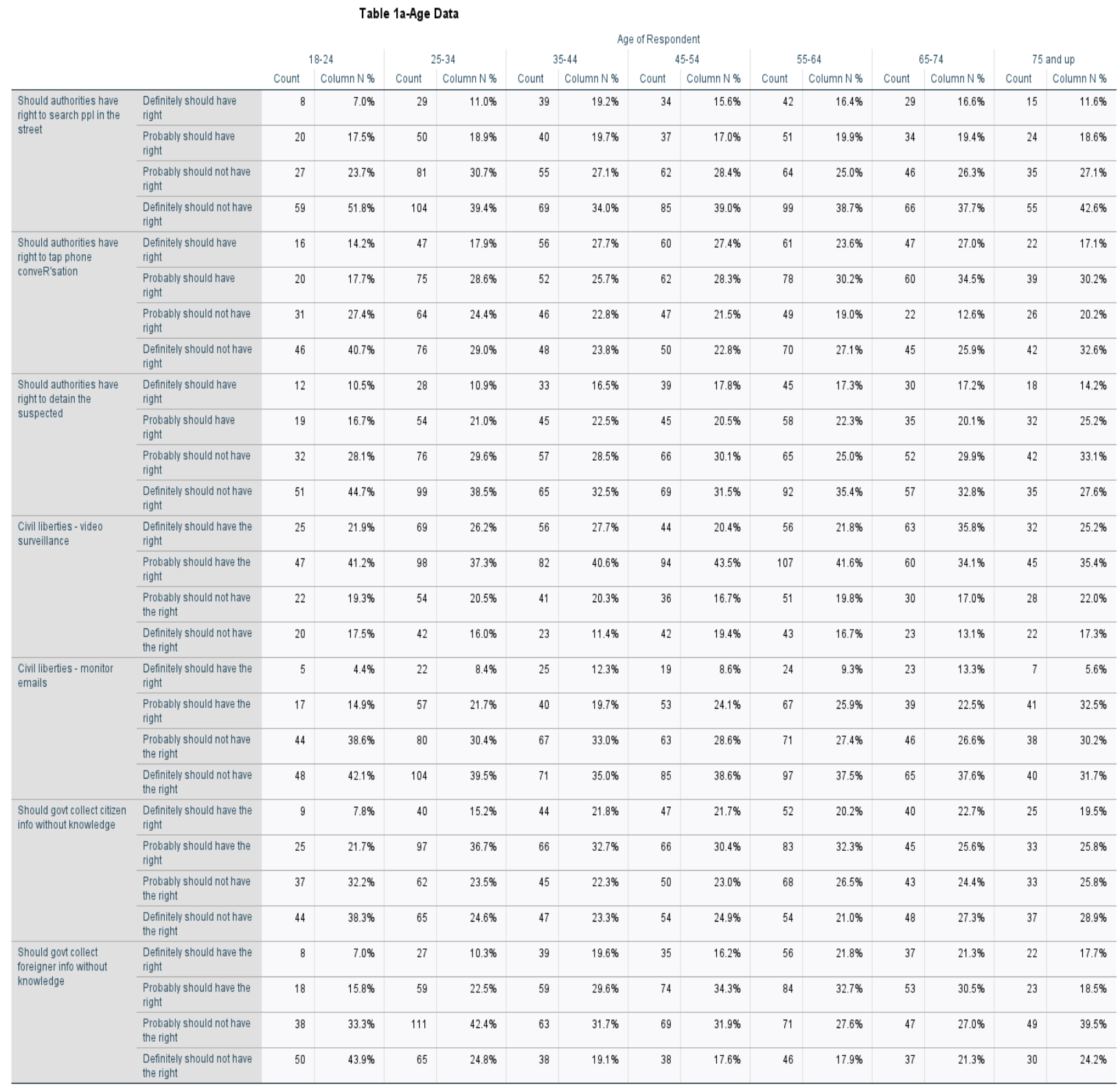


Table 2a-Sex Data

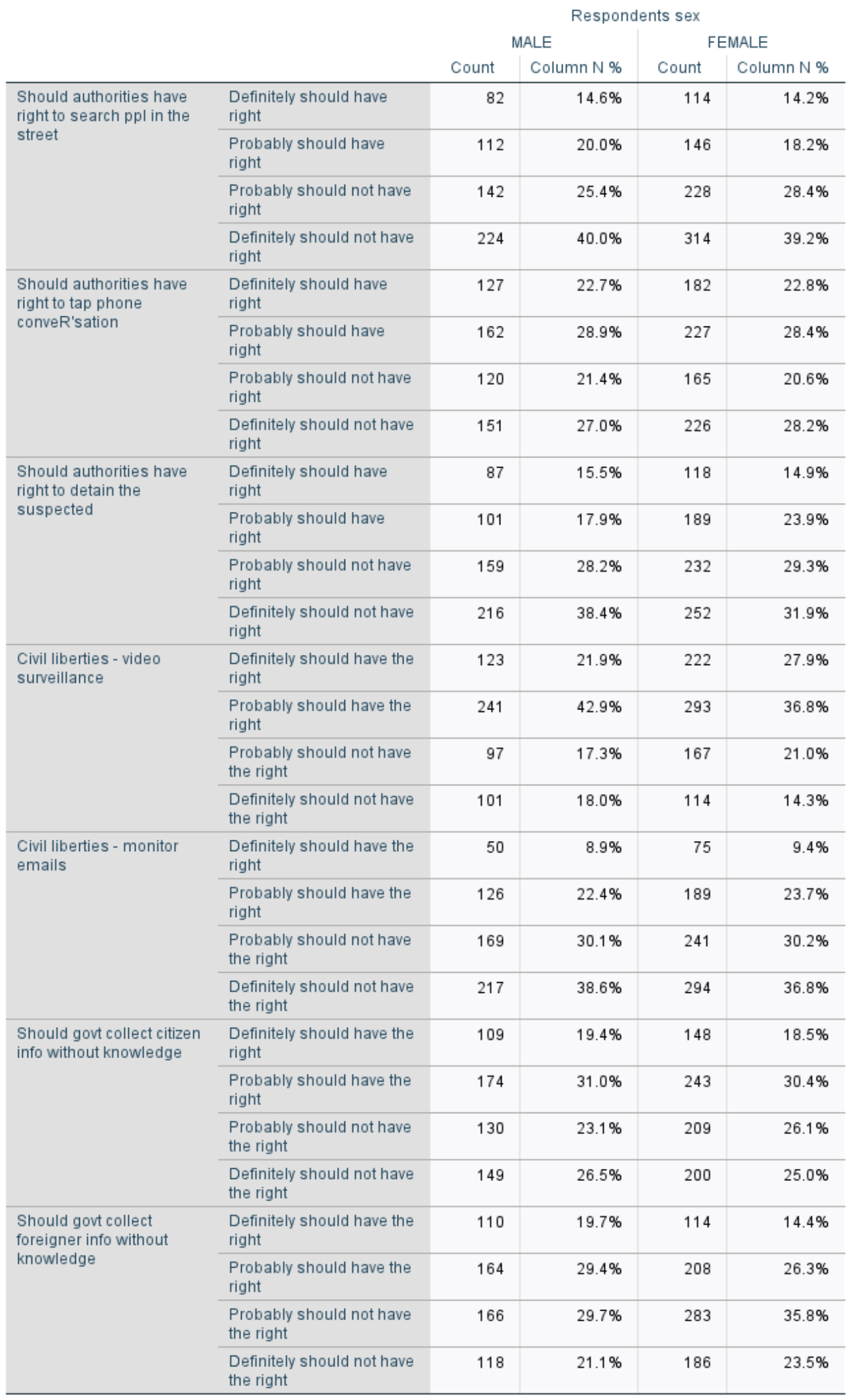


Table 3a-Race Data

\begin{tabular}{|c|c|c|c|c|c|c|c|}
\hline & \multicolumn{6}{|c|}{ Race of respondent } \\
\hline & & \multicolumn{2}{|c|}{ WHITE } & \multicolumn{2}{|c|}{ BLACK } & \multicolumn{2}{|c|}{ OTHER } \\
\hline & & Count & Column N \% & Count & Column N \% & Count & Column N \% \\
\hline \multirow{4}{*}{$\begin{array}{l}\text { Should authorities have } \\
\text { right to search ppl in the } \\
\text { street }\end{array}$} & $\begin{array}{l}\text { Definitely should have } \\
\text { right }\end{array}$ & 152 & $15.2 \%$ & 25 & $11.1 \%$ & 19 & $13.6 \%$ \\
\hline & $\begin{array}{l}\text { Probably should have } \\
\text { right }\end{array}$ & 197 & $19.8 \%$ & 31 & $13.8 \%$ & 30 & $21.4 \%$ \\
\hline & $\begin{array}{l}\text { Probably should not have } \\
\text { right }\end{array}$ & 279 & $28.0 \%$ & 54 & $24.0 \%$ & 37 & $26.4 \%$ \\
\hline & $\begin{array}{l}\text { Definitely should not have } \\
\text { right }\end{array}$ & 369 & $37.0 \%$ & 115 & $51.1 \%$ & 54 & $38.6 \%$ \\
\hline \multirow{4}{*}{$\begin{array}{l}\text { Should authorities have } \\
\text { right to tap phone } \\
\text { conveR'sation }\end{array}$} & $\begin{array}{l}\text { Definitely should have } \\
\text { right }\end{array}$ & 240 & $24.1 \%$ & 42 & $18.8 \%$ & 27 & $19.1 \%$ \\
\hline & $\begin{array}{l}\text { Probably should have } \\
\text { right }\end{array}$ & 287 & $28.8 \%$ & 64 & $28.6 \%$ & 38 & $27.0 \%$ \\
\hline & $\begin{array}{l}\text { Probably should not have } \\
\text { right }\end{array}$ & 211 & $21.2 \%$ & 38 & $17.0 \%$ & 36 & $25.5 \%$ \\
\hline & $\begin{array}{l}\text { Definitely should not have } \\
\text { right }\end{array}$ & 257 & $25.8 \%$ & 80 & $35.7 \%$ & 40 & $28.4 \%$ \\
\hline \multirow{4}{*}{$\begin{array}{l}\text { Should authorities have } \\
\text { right to detain the } \\
\text { suspected }\end{array}$} & $\begin{array}{l}\text { Definitely should have } \\
\text { right }\end{array}$ & 136 & $13.6 \%$ & 39 & $17.6 \%$ & 30 & $22.4 \%$ \\
\hline & $\begin{array}{l}\text { Probably should have } \\
\text { right }\end{array}$ & 208 & $20.8 \%$ & 47 & $21.2 \%$ & 35 & $26.1 \%$ \\
\hline & $\begin{array}{l}\text { Probably should not have } \\
\text { right }\end{array}$ & 303 & $30.4 \%$ & 63 & $28.4 \%$ & 25 & $18.7 \%$ \\
\hline & $\begin{array}{l}\text { Definitely should not have } \\
\text { right }\end{array}$ & 351 & $35.2 \%$ & 73 & $32.9 \%$ & 44 & $32.8 \%$ \\
\hline \multirow[t]{4}{*}{$\begin{array}{l}\text { Civil liberties - video } \\
\text { surveillance }\end{array}$} & $\begin{array}{l}\text { Definitely should have the } \\
\text { right }\end{array}$ & 251 & $25.2 \%$ & 65 & $29.0 \%$ & 29 & $20.9 \%$ \\
\hline & $\begin{array}{l}\text { Probably should have the } \\
\text { right }\end{array}$ & 397 & $39.9 \%$ & 80 & $35.7 \%$ & 57 & $41.0 \%$ \\
\hline & $\begin{array}{l}\text { Probably should not have } \\
\text { the right }\end{array}$ & 201 & $20.2 \%$ & 35 & $15.6 \%$ & 28 & $20.1 \%$ \\
\hline & $\begin{array}{l}\text { Definitely should not have } \\
\text { the right }\end{array}$ & 146 & $14.7 \%$ & 44 & $19.6 \%$ & 25 & $18.0 \%$ \\
\hline \multirow[t]{4}{*}{$\begin{array}{l}\text { Civil liberties - monitor } \\
\text { emails }\end{array}$} & $\begin{array}{l}\text { Definitely should have the } \\
\text { right }\end{array}$ & 92 & $9.2 \%$ & 26 & $11.6 \%$ & 7 & $5.0 \%$ \\
\hline & $\begin{array}{l}\text { Probably should have the } \\
\text { right }\end{array}$ & 224 & $22.5 \%$ & 55 & $24.4 \%$ & 36 & $25.7 \%$ \\
\hline & $\begin{array}{l}\text { Probably should not have } \\
\text { the right }\end{array}$ & 310 & $31.1 \%$ & 62 & $27.6 \%$ & 38 & $27.1 \%$ \\
\hline & $\begin{array}{l}\text { Definitely should not have } \\
\text { the right }\end{array}$ & 370 & $37.1 \%$ & 82 & $36.4 \%$ & 59 & $42.1 \%$ \\
\hline \multirow[t]{4}{*}{$\begin{array}{l}\text { Should govt collect citizen } \\
\text { info without knowledge }\end{array}$} & $\begin{array}{l}\text { Definitely should have the } \\
\text { right }\end{array}$ & 177 & $17.8 \%$ & 54 & $23.9 \%$ & 26 & $18.7 \%$ \\
\hline & $\begin{array}{l}\text { Probably should have the } \\
\text { right }\end{array}$ & 311 & $31.2 \%$ & 68 & $30.1 \%$ & 38 & $27.3 \%$ \\
\hline & $\begin{array}{l}\text { Probably should not have } \\
\text { the right }\end{array}$ & 250 & $25.1 \%$ & 52 & $23.0 \%$ & 37 & $26.6 \%$ \\
\hline & $\begin{array}{l}\text { Definitely should not have } \\
\text { the right }\end{array}$ & 259 & $26.0 \%$ & 52 & $23.0 \%$ & 38 & $27.3 \%$ \\
\hline \multirow{4}{*}{$\begin{array}{l}\text { Should govt collect } \\
\text { foreigner info without } \\
\text { knowledge }\end{array}$} & $\begin{array}{l}\text { Definitely should have the } \\
\text { right }\end{array}$ & 155 & $15.6 \%$ & 50 & $22.4 \%$ & 19 & $14.1 \%$ \\
\hline & $\begin{array}{l}\text { Probably should have the } \\
\text { right }\end{array}$ & 286 & $28.9 \%$ & 57 & $25.6 \%$ & 29 & $21.5 \%$ \\
\hline & $\begin{array}{l}\text { Probably should not have } \\
\text { the right }\end{array}$ & 344 & $34.7 \%$ & 57 & $25.6 \%$ & 48 & $35.6 \%$ \\
\hline & $\begin{array}{l}\text { Definitely should not have } \\
\text { the right }\end{array}$ & 206 & $20.8 \%$ & 59 & $26.5 \%$ & 39 & $28.9 \%$ \\
\hline
\end{tabular}


Table 4a-Degree Data

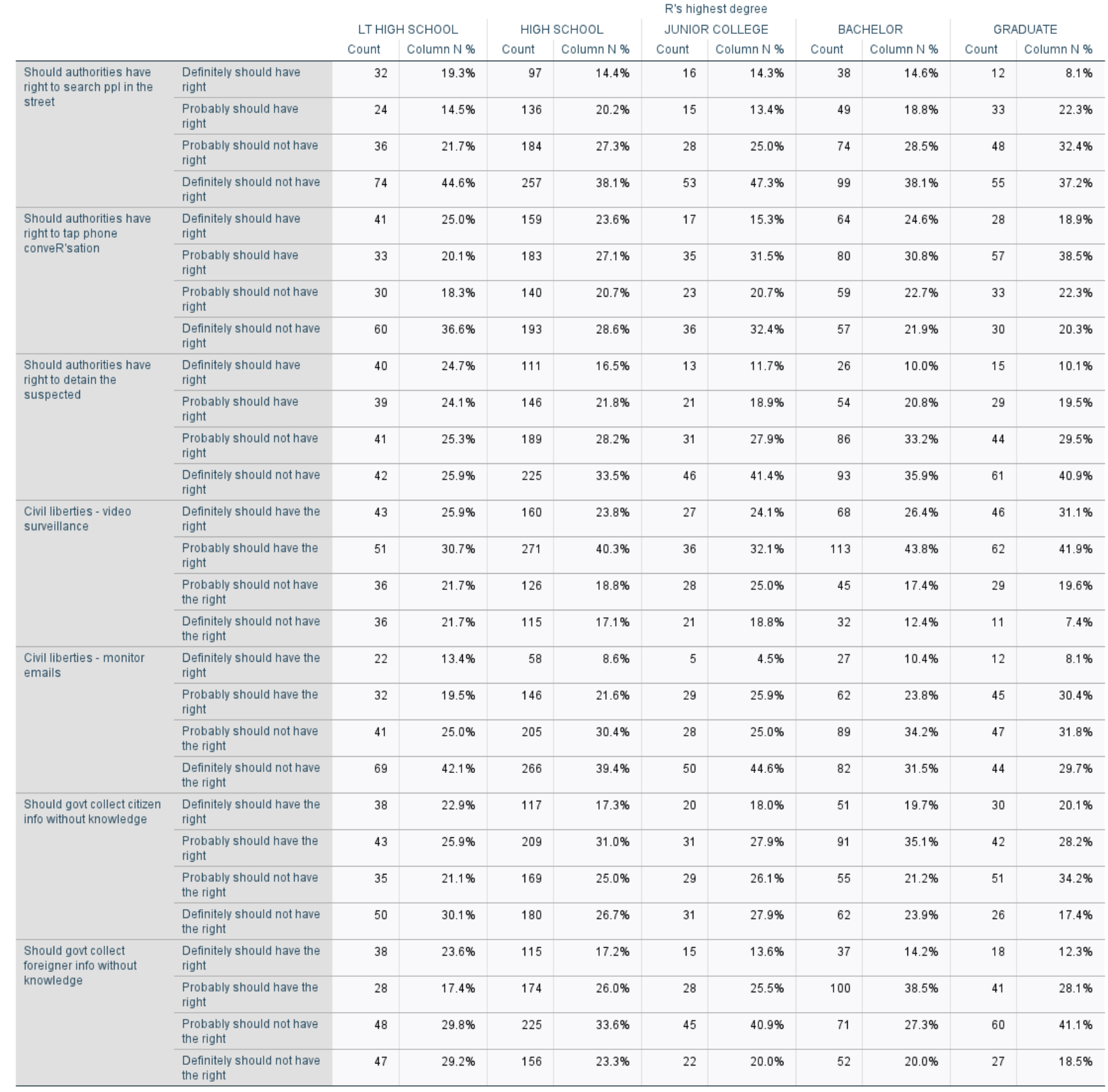




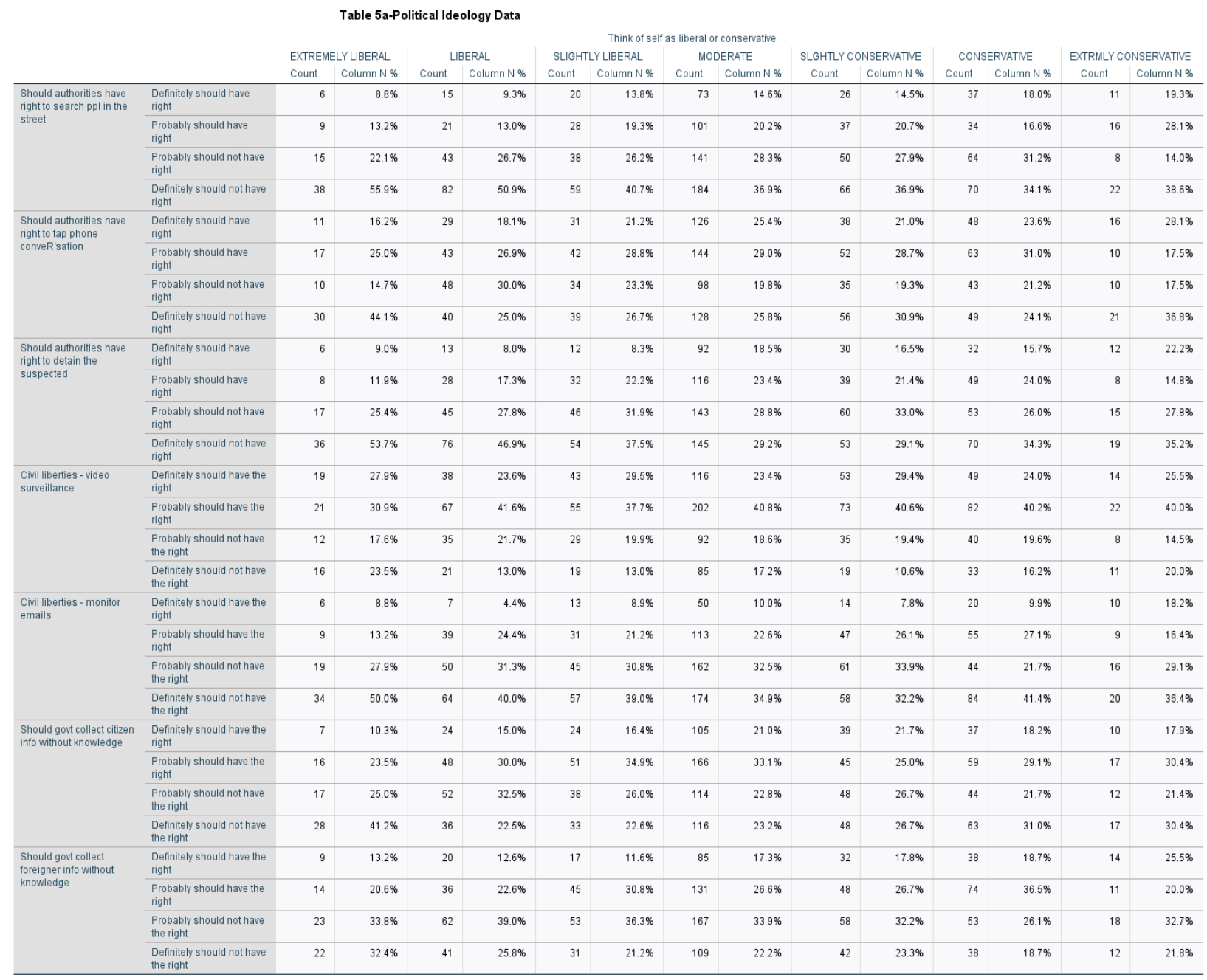




\begin{tabular}{|c|c|c|c|c|c|c|c|c|c|c|c|c|c|c|c|c|c|c|c|c|c|}
\hline \multicolumn{22}{|c|}{ Table 6a and 7a-Trust in Administartors and in Congress to Keep Promises } \\
\hline & & \multicolumn{10}{|c|}{ Wost government administratte's's can be trusted } & \multicolumn{10}{|c|}{ People elected to congress tryto keep promises } \\
\hline & & \multicolumn{2}{|c|}{ STRONGLYAGREE } & \multicolumn{2}{|c|}{ AGREE } & \multicolumn{2}{|c|}{$\begin{array}{l}\text { NETHER AGREE NOR } \\
\text { DISAGREE }\end{array}$} & \multicolumn{2}{|c|}{ DISAGREE } & \multicolumn{2}{|c|}{ STRONGLY DISAGREE } & \multicolumn{2}{|c|}{ STRONGLYAGREE } & \multicolumn{2}{|c|}{ AGREE } & \multicolumn{2}{|c|}{$\begin{array}{l}\text { NETHER AGREE NOR } \\
\text { DISAGREE }\end{array}$} & \multicolumn{2}{|c|}{ DISAGREE } & \multicolumn{2}{|c|}{ STRONGLY DISAGREE } \\
\hline & & Count & Column $\mathrm{N} \%$ & Count & Column N\% & count & Column N\% & count & Column N\% & Count & Column N\% & Count & Column N\% & count & Column N\% & count & Column N\% & Count & Column N\% & Count & Column N\% \\
\hline \multirow{4}{*}{$\begin{array}{l}\begin{array}{l}\text { Should authoritas hare } \\
\text { right } \\
\text { street }\end{array}\end{array}$} & $\begin{array}{l}\text { Defnitey should hare } \\
\text { right }\end{array}$ & 4 & $18.2 \%$ & 43 & $15.9 \%$ & 51 & 13.1\% & 62 & $12.2 \%$ & 35 & $21.0 \%$ & 8 & $222 \%$ & 37 & $15.2 \%$ & 42 & $14.0 \%$ & 70 & $13.0 \%$ & 39 & $16.3 \%$ \\
\hline & $\begin{array}{l}\text { Probably should hare } \\
\text { right }\end{array}$ & 1 & $4.5 \%$ & 63 & $233 \%$ & 79 & $20.3 \%$ & 96 & $18.9 \%$ & 19 & $11.4 \%$ & 4 & $11.1 \%$ & 53 & $21.8 \%$ & 73 & $24.3 \%$ & 95 & $17.7 \%$ & 32 & $13.4 \%$ \\
\hline & $\begin{array}{l}\begin{array}{l}\text { Probably should not hare } \\
\text { fight }\end{array} \\
\text { S }\end{array}$ & 6 & $27.3 \%$ & 65 & $24.1 \%$ & 114 & $29.3 \%$ & 146 & $28.7 \%$ & 39 & $23.4 \%$ & 5 & $1398 \%$ & 49 & $20.2 \%$ & 87 & $28.9 \%$ & 166 & $30.9 \%$ & 61 & $25.5 \%$ \\
\hline & $\begin{array}{l}\text { Defnitey should not have } \\
\text { right }\end{array}$ & 11 & $50.0 \%$ & 99 & $36.7 \%$ & 145 & $37.3 \%$ & 204 & $40.2 \%$ & 74 & $44.3 \%$ & 19 & $528 \%$ & 104 & $42.8 \%$ & 99 & $32.9 \%$ & 206 & $38.4 \%$ & 107 & $44.8 \%$ \\
\hline \multirow{4}{*}{ 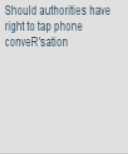 } & $\begin{array}{l}\text { Definter/should hare } \\
\text { right }\end{array}$ & 10 & $45.5 \%$ & 64 & $23.9 \%$ & 84 & $21.5 \%$ & 102 & $20.2 \%$ & 45 & $27.1 \%$ & 8 & $222 \%$ & 58 & $23.6 \%$ & 66 & $22.1 \%$ & 116 & $21.8 \%$ & 59 & $24.6 \%$ \\
\hline & $\begin{array}{l}\begin{array}{l}\text { Probatly should hare } \\
\text { right }\end{array} \\
\end{array}$ & 5 & $22.7 \%$ & 87 & $325 \%$ & 110 & $282 \%$ & 146 & $28.9 \%$ & 41 & $24.7 \%$ & 4 & $11.1 \%$ & 74 & $30.1 \%$ & 93 & $31.2 \%$ & 155 & $29.1 \%$ & 62 & $25.8 \%$ \\
\hline & 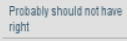 & 2 & $9.1 \%$ & 43 & $16.0 \%$ & 103 & $26.4 \%$ & 111 & $21.9 \%$ & 25 & $15.1 \%$ & 7 & $19.4 \%$ & 45 & $18.3 \%$ & 69 & $23.2 \%$ & 123 & $23.1 \%$ & 39 & $16.3 \%$ \\
\hline & $\begin{array}{l}\text { Defnitey should not have } \\
\text { right }\end{array}$ & 5 & $22.7 \%$ & 74 & $27.6 \%$ & 93 & $238 \%$ & 147 & $29.1 \%$ & 55 & $33.1 \%$ & 17 & $47.2 \%$ & 69 & 28.0\% & 70 & $23.5 \%$ & 138 & $25.9 \%$ & 80 & $33.3 \%$ \\
\hline \multirow{4}{*}{$\begin{array}{l}\text { Should authoritas hare } \\
\text { rigntit detain hle } \\
\text { suspected }\end{array}$} & $\begin{array}{l}\text { Defintely should hare } \\
\text { right }\end{array}$ & 9 & $40.9 \%$ & 36 & $13.6 \%$ & 44 & 11.4\% & 76 & $15.0 \%$ & 39 & $23.6 \%$ & 11 & $324 \%$ & 35 & $14.5 \%$ & 34 & $11.5 \%$ & 83 & $15.5 \%$ & 42 & $17.6 \%$ \\
\hline & $\begin{array}{l}\text { Probably should hare } \\
\text { right }\end{array}$ & 3 & $13.6 \%$ & 60 & $226 \%$ & 100 & $258 \%$ & 97 & $19.1 \%$ & 29 & $17.6 \%$ & 7 & $20.6 \%$ & 55 & $227 \%$ & 68 & $23.0 \%$ & 107 & $20.0 \%$ & 50 & 20.98 \\
\hline & $\begin{array}{l}\text { Probably shoult not hare } \\
\text { right }\end{array}$ & 3 & $13.6 \%$ & 77 & $29.1 \%$ & 120 & $31.0 \%$ & 157 & $30.9 \%$ & 31 & $18.8 \%$ & 3 & $88 \%$ & 67 & $27.7 \%$ & 93 & $31.4 \%$ & 172 & $321 \%$ & 54 & $22.6 \%$ \\
\hline & $\begin{array}{l}\text { Defniter should not have } \\
\text { right }\end{array}$ & 7 & $31.8 \%$ & 92 & $34.7 \%$ & 123 & $31.8 \%$ & 178 & $35.0 \%$ & 66 & $40.0 \%$ & 13 & $382 \%$ & 85 & 35.1\% & 101 & $34.1 \%$ & 174 & $325 \%$ & 93 & $38.9 \%$ \\
\hline \multirow[t]{4}{*}{$\begin{array}{l}\text { Cimllibertias - video } \\
\text { survellance }\end{array}$} & $\begin{array}{l}\text { Defnitey should have the } \\
\text { right }\end{array}$ & 7 & $31.8 \%$ & 80 & $30.1 \%$ & 85 & $21.8 \%$ & 131 & $25.8 \%$ & 38 & 22.98 & 9 & $25.0 \%$ & 70 & 28.8\% & 74 & $24.8 \%$ & 120 & $224 \%$ & 69 & $29.0 \%$ \\
\hline & $\begin{array}{l}\text { Protobally should have he } \\
\text { right }\end{array}$ & 9 & $40.9 \%$ & 102 & $383 \%$ & 178 & $45.6 \%$ & 184 & $36.3 \%$ & 60 & $36.1 \%$ & 11 & $30.6 \%$ & 97 & $39.9 \%$ & 125 & $41.9 \%$ & 222 & $41.4 \%$ & 78 & $328 \%$ \\
\hline & $\begin{array}{l}\begin{array}{l}\text { Probably shoult not hare } \\
\text { the right }\end{array} \\
\end{array}$ & 4 & $18.2 \%$ & 53 & $19.9 \%$ & 82 & $210 \%$ & 98 & $19.3 \%$ & 26 & $15.7 \%$ & 9 & $250 \%$ & 43 & $17.7 \%$ & 65 & $21.8 \%$ & 111 & $20.7 \%$ & 35 & $14.7 \%$ \\
\hline & $\begin{array}{l}\text { Defnitery should not have } \\
\text { the right }\end{array}$ & 2 & $9.1 \%$ & 31 & $11.7 \%$ & 45 & $11.5 \%$ & 94 & $18.5 \%$ & 42 & $25.3 \%$ & 7 & $19.4 \%$ & 33 & $13.6 \%$ & 34 & $11.4 \%$ & 83 & $15.5 \%$ & 56 & $23.5 \%$ \\
\hline \multirow[t]{4}{*}{$\begin{array}{l}\text { Cinil litertilies - monitor } \\
\text { emalis }\end{array}$} & $\begin{array}{l}\text { Defntely should hare the } \\
\text { right }\end{array}$ & 5 & $23.8 \%$ & 27 & $10.0 \%$ & 27 & $6.9 \%$ & 49 & $9.7 \%$ & 16 & $9.5 \%$ & 4 & $11.4 \%$ & 21 & $8.5 \%$ & 24 & $8.0 \%$ & 51 & $9.5 \%$ & 24 & $10.1 \%$ \\
\hline & $\begin{array}{l}\text { Probably shoulth hare the } \\
\text { right }\end{array}$ & 5 & $23.8 \%$ & 80 & $29.7 \%$ & 98 & $25.1 \%$ & 97 & $19.2 \%$ & 33 & $19.6 \%$ & 6 & $17.1 \%$ & 67 & $27.2 \%$ & 71 & $23.7 \%$ & 128 & $23.9 \%$ & 42 & $17.6 \%$ \\
\hline & $\begin{array}{l}\begin{array}{l}\text { Probably should not hare } \\
\text { the right }\end{array} \\
\end{array}$ & 6 & $28.6 \%$ & 81 & $30.1 \%$ & 125 & $321 \%$ & 164 & $32.5 \%$ & 32 & $19.0 \%$ & 8 & $229 \%$ & 69 & $28.0 \%$ & 111 & $37.0 \%$ & 164 & $30.7 \%$ & 57 & $23.9 \%$ \\
\hline & $\begin{array}{l}\text { Defentert should not have } \\
\text { the right }\end{array}$ & 5 & $23.8 \%$ & 81 & $30.1 \%$ & 140 & $35.9 \%$ & 195 & $38.6 \%$ & 87 & $51.8 \%$ & 17 & $48.6 \%$ & 89 & $36.2 \%$ & 94 & $31.3 \%$ & 192 & $35.9 \%$ & 115 & $48.3 \%$ \\
\hline \multirow[t]{4}{*}{ 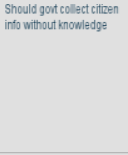 } & $\begin{array}{l}\text { Defintelt should have the } \\
\text { right }\end{array}$ & 8 & $36.4 \%$ & 54 & $20.1 \%$ & 78 & $199 \%$ & 85 & $16.8 \%$ & 29 & $17.5 \%$ & 11 & $30.6 \%$ & 51 & $20.9 \%$ & 53 & $17.7 \%$ & 96 & $17.9 \%$ & 44 & $18.4 \%$ \\
\hline & $\begin{array}{l}\text { Probablly should hare the } \\
\text { right }\end{array}$ & 5 & $22.7 \%$ & 93 & $34.7 \%$ & 122 & $312 \%$ & 149 & $29.4 \%$ & 48 & $28.9 \%$ & 3 & $83 \%$ & 84 & $34.4 \%$ & 96 & $32.1 \%$ & 172 & $32.1 \%$ & 59 & $24.7 \%$ \\
\hline & $\begin{array}{l}\begin{array}{l}\text { Probably shoult not hare } \\
\text { the right }\end{array}\end{array}$ & 2 & $9.1 \%$ & 64 & $239 \%$ & 112 & $286 \%$ & 133 & $26.2 \%$ & 26 & $15.7 \%$ & 7 & $19.4 \%$ & 57 & $23.4 \%$ & 94 & $31.4 \%$ & 136 & $25.4 \%$ & 44 & 18.48 \\
\hline & $\begin{array}{l}\text { Defintely should not have } \\
\text { the right }\end{array}$ & 7 & $31.8 \%$ & 57 & $21.3 \%$ & 79 & $20.2 \%$ & 140 & $27.6 \%$ & 63 & $38.0 \%$ & 15 & $41.7 \%$ & 52 & $21.3 \%$ & 56 & $18.7 \%$ & 132 & $24.6 \%$ & 92 & $38.5 \%$ \\
\hline \multirow{4}{*}{$\begin{array}{l}\text { Shoullagort collect } \\
\text { toreigne into without } \\
\text { knowiedge }\end{array}$} & $\begin{array}{l}\text { Defnitery should have the } \\
\text { right }\end{array}$ & 9 & $40.9 \%$ & 40 & $15.0 \%$ & 56 & $14.4 \%$ & 81 & $16.2 \%$ & 35 & $21.2 \%$ & 8 & $23.5 \%$ & 41 & $16.8 \%$ & 40 & $13.5 \%$ & 82 & $15.4 \%$ & 51 & $21.7 \%$ \\
\hline & $\begin{array}{l}\text { Probatly shoult have the } \\
\text { right }\end{array}$ & 4 & $18.2 \%$ & 80 & $30.1 \%$ & 107 & $27.6 \%$ & 139 & $27.8 \%$ & 41 & $24.8 \%$ & 7 & $20.6 \%$ & 69 & $28.3 \%$ & 81 & $27.4 \%$ & 161 & $30.3 \%$ & 51 & $21.7 \%$ \\
\hline & $\begin{array}{l}\text { Provably should nothare } \\
\text { the right }\end{array}$ & 4 & $18.2 \%$ & 89 & $33.5 \%$ & 142 & $36.6 \%$ & 170 & $34.0 \%$ & 42 & $25.5 \%$ & 7 & $20.6 \%$ & 80 & $32.8 \%$ & 115 & $38.9 \%$ & 179 & $33.6 \%$ & 66 & 28.18 \\
\hline & $\begin{array}{l}\text { Defintery should not have } \\
\text { the right }\end{array}$ & 5 & $22.7 \%$ & 57 & $21.4 \%$ & 83 & $21.4 \%$ & 110 & $22.0 \%$ & 47 & $28.5 \%$ & 12 & $35.3 \%$ & 54 & $22.1 \%$ & 60 & $20.3 \%$ & 110 & $20.7 \%$ & 67 & $28.5 \%$ \\
\hline
\end{tabular}


Table 8a-Confidence in Military

\begin{tabular}{|c|c|c|c|c|c|c|c|}
\hline & & \multicolumn{6}{|c|}{ Confidence in military } \\
\hline & & \multicolumn{2}{|c|}{ A GREAT DEAL } & \multicolumn{2}{|c|}{ ONLY SOME } & \multicolumn{2}{|c|}{ HARDLY ANY } \\
\hline & & Count & Column N \% & Count & Column N \% & Count & Column N \% \\
\hline \multirow{4}{*}{$\begin{array}{l}\text { Should authorities have } \\
\text { right to search ppl in the } \\
\text { street }\end{array}$} & $\begin{array}{l}\text { Definitely should have } \\
\text { right }\end{array}$ & 29 & $13.2 \%$ & 21 & $10.2 \%$ & 6 & $14.3 \%$ \\
\hline & $\begin{array}{l}\text { Probably should have } \\
\text { right }\end{array}$ & 52 & $23.6 \%$ & 33 & $16.0 \%$ & 3 & $7.1 \%$ \\
\hline & $\begin{array}{l}\text { Probably should not have } \\
\text { right }\end{array}$ & 65 & $29.5 \%$ & 59 & $28.6 \%$ & 7 & $16.7 \%$ \\
\hline & $\begin{array}{l}\text { Definitely should not have } \\
\text { right }\end{array}$ & 74 & $33.6 \%$ & 93 & $45.1 \%$ & 26 & $61.9 \%$ \\
\hline \multirow{4}{*}{$\begin{array}{l}\text { Should authorities have } \\
\text { right to tap phone } \\
\text { conveR'sation }\end{array}$} & $\begin{array}{l}\text { Definitely should have } \\
\text { right }\end{array}$ & 51 & $23.4 \%$ & 33 & $16.2 \%$ & 9 & $20.9 \%$ \\
\hline & $\begin{array}{l}\text { Probably should have } \\
\text { right }\end{array}$ & 66 & $30.3 \%$ & 55 & $27.0 \%$ & 4 & $9.3 \%$ \\
\hline & $\begin{array}{l}\text { Probably should not have } \\
\text { right }\end{array}$ & 44 & $20.2 \%$ & 59 & $28.9 \%$ & 7 & $16.3 \%$ \\
\hline & $\begin{array}{l}\text { Definitely should not have } \\
\text { right }\end{array}$ & 57 & $26.1 \%$ & 57 & $27.9 \%$ & 23 & $53.5 \%$ \\
\hline \multirow{4}{*}{$\begin{array}{l}\text { Should authorities have } \\
\text { right to detain the } \\
\text { suspected }\end{array}$} & $\begin{array}{l}\text { Definitely should have } \\
\text { right }\end{array}$ & 41 & $18.9 \%$ & 19 & $9.2 \%$ & 7 & $16.3 \%$ \\
\hline & $\begin{array}{l}\text { Probably should have } \\
\text { right }\end{array}$ & 60 & $27.6 \%$ & 34 & $16.5 \%$ & 6 & $14.0 \%$ \\
\hline & $\begin{array}{l}\text { Probably should not have } \\
\text { right }\end{array}$ & 61 & $28.1 \%$ & 66 & $32.0 \%$ & 9 & $20.9 \%$ \\
\hline & $\begin{array}{l}\text { Definitely should not have } \\
\text { right }\end{array}$ & 55 & $25.3 \%$ & 87 & $42.2 \%$ & 21 & $48.8 \%$ \\
\hline \multirow[t]{4}{*}{$\begin{array}{l}\text { Civil liberties - video } \\
\text { surveillance }\end{array}$} & $\begin{array}{l}\text { Definitely should have the } \\
\text { right }\end{array}$ & 63 & $28.8 \%$ & 52 & $25.2 \%$ & 10 & $24.4 \%$ \\
\hline & $\begin{array}{l}\text { Probably should have the } \\
\text { right }\end{array}$ & 86 & $39.3 \%$ & 88 & $42.7 \%$ & 11 & $26.8 \%$ \\
\hline & $\begin{array}{l}\text { Probably should not have } \\
\text { the right }\end{array}$ & 42 & $19.2 \%$ & 40 & $19.4 \%$ & 9 & $22.0 \%$ \\
\hline & $\begin{array}{l}\text { Definitely should not have } \\
\text { the right }\end{array}$ & 28 & $12.8 \%$ & 26 & $12.6 \%$ & 11 & $26.8 \%$ \\
\hline \multirow[t]{4}{*}{$\begin{array}{l}\text { Civil liberties - monitor } \\
\text { emails }\end{array}$} & $\begin{array}{l}\text { Definitely should have the } \\
\text { right }\end{array}$ & 23 & $10.6 \%$ & 19 & $9.1 \%$ & 2 & $4.7 \%$ \\
\hline & $\begin{array}{l}\text { Probably should have the } \\
\text { right }\end{array}$ & 53 & $24.3 \%$ & 52 & $25.0 \%$ & 6 & $14.0 \%$ \\
\hline & $\begin{array}{l}\text { Probably should not have } \\
\text { the right }\end{array}$ & 60 & $27.5 \%$ & 62 & $29.8 \%$ & 6 & $14.0 \%$ \\
\hline & $\begin{array}{l}\text { Definitely should not have } \\
\text { the right }\end{array}$ & 82 & $37.6 \%$ & 75 & $36.1 \%$ & 29 & $67.4 \%$ \\
\hline \multirow[t]{4}{*}{$\begin{array}{l}\text { Should govt collect citizen } \\
\text { info without knowledge }\end{array}$} & $\begin{array}{l}\text { Definitely should have the } \\
\text { right }\end{array}$ & 45 & $20.5 \%$ & 22 & $10.7 \%$ & 3 & $7.0 \%$ \\
\hline & $\begin{array}{l}\text { Probably should have the } \\
\text { right }\end{array}$ & 67 & $30.5 \%$ & 75 & $36.4 \%$ & 7 & $16.3 \%$ \\
\hline & $\begin{array}{l}\text { Probably should not have } \\
\text { the right }\end{array}$ & 56 & $25.5 \%$ & 58 & $28.2 \%$ & 9 & $20.9 \%$ \\
\hline & $\begin{array}{l}\text { Definitely should not have } \\
\text { the right }\end{array}$ & 52 & $23.6 \%$ & 51 & $24.8 \%$ & 24 & $55.8 \%$ \\
\hline \multirow{4}{*}{$\begin{array}{l}\text { Should govt collect } \\
\text { foreigner info without } \\
\text { knowledge }\end{array}$} & $\begin{array}{l}\text { Definitely should have the } \\
\text { right }\end{array}$ & 41 & $18.8 \%$ & 25 & $12.4 \%$ & 6 & $14.0 \%$ \\
\hline & $\begin{array}{l}\text { Probably should have the } \\
\text { right }\end{array}$ & 65 & $29.8 \%$ & 60 & $29.7 \%$ & 5 & $11.6 \%$ \\
\hline & $\begin{array}{l}\text { Probably should not have } \\
\text { the right }\end{array}$ & 72 & $33.0 \%$ & 67 & $33.2 \%$ & 12 & $27.9 \%$ \\
\hline & $\begin{array}{l}\text { Definitely should not have } \\
\text { the right }\end{array}$ & 40 & $18.3 \%$ & 50 & $24.8 \%$ & 20 & $46.5 \%$ \\
\hline
\end{tabular}


Table 9a-Confidence in the Executive

\begin{tabular}{|c|c|c|c|c|c|c|c|}
\hline & & \multicolumn{6}{|c|}{ Confid. in exec branch of fed govt } \\
\hline & & \multicolumn{2}{|c|}{ A GREAT DEAL } & \multicolumn{2}{|c|}{ ONLY SOME } & \multicolumn{2}{|c|}{ HARDLY ANY } \\
\hline & & Count & Column N \% & Count & Column N \% & Count & Column N \% \\
\hline \multirow{4}{*}{$\begin{array}{l}\text { Should authorities have } \\
\text { right to search ppl in the } \\
\text { street }\end{array}$} & $\begin{array}{l}\text { Definitely should have } \\
\text { right }\end{array}$ & 4 & $8.7 \%$ & 22 & $11.4 \%$ & 30 & $13.5 \%$ \\
\hline & $\begin{array}{l}\text { Probably should have } \\
\text { right }\end{array}$ & 11 & $23.9 \%$ & 38 & $19.7 \%$ & 39 & $17.5 \%$ \\
\hline & $\begin{array}{l}\text { Probably should not have } \\
\text { right }\end{array}$ & 14 & $30.4 \%$ & 58 & $30.1 \%$ & 55 & $24.7 \%$ \\
\hline & $\begin{array}{l}\text { Definitely should not have } \\
\text { right }\end{array}$ & 17 & $37.0 \%$ & 75 & $38.9 \%$ & 99 & $44.4 \%$ \\
\hline \multirow{4}{*}{$\begin{array}{l}\text { Should authorities have } \\
\text { right to tap phone } \\
\text { conveR'sation }\end{array}$} & $\begin{array}{l}\text { Definitely should have } \\
\text { right }\end{array}$ & 12 & $26.1 \%$ & 34 & $17.9 \%$ & 48 & $21.5 \%$ \\
\hline & $\begin{array}{l}\text { Probably should have } \\
\text { right }\end{array}$ & 12 & $26.1 \%$ & 54 & $28.4 \%$ & 56 & $25.1 \%$ \\
\hline & $\begin{array}{l}\text { Probably should not have } \\
\text { right }\end{array}$ & 10 & $21.7 \%$ & 44 & $23.2 \%$ & 54 & $24.2 \%$ \\
\hline & $\begin{array}{l}\text { Definitely should not have } \\
\text { right }\end{array}$ & 12 & $26.1 \%$ & 58 & $30.5 \%$ & 65 & $29.1 \%$ \\
\hline \multirow{4}{*}{$\begin{array}{l}\text { Should authorities have } \\
\text { right to detain the } \\
\text { suspected }\end{array}$} & $\begin{array}{l}\text { Definitely should have } \\
\text { right }\end{array}$ & 7 & $15.9 \%$ & 25 & $12.9 \%$ & 37 & $16.7 \%$ \\
\hline & $\begin{array}{l}\text { Probably should have } \\
\text { right }\end{array}$ & 13 & $29.5 \%$ & 46 & $23.7 \%$ & 38 & $17.1 \%$ \\
\hline & $\begin{array}{l}\text { Probably should not have } \\
\text { right }\end{array}$ & 12 & $27.3 \%$ & 57 & $29.4 \%$ & 67 & $30.2 \%$ \\
\hline & $\begin{array}{l}\text { Definitely should not have } \\
\text { right }\end{array}$ & 12 & $27.3 \%$ & 66 & $34.0 \%$ & 80 & $36.0 \%$ \\
\hline \multirow[t]{4}{*}{$\begin{array}{l}\text { Civil liberties - video } \\
\text { surveillance }\end{array}$} & $\begin{array}{l}\text { Definitely should have the } \\
\text { right }\end{array}$ & 19 & $41.3 \%$ & 55 & $28.4 \%$ & 50 & $22.7 \%$ \\
\hline & $\begin{array}{l}\text { Probably should have the } \\
\text { right }\end{array}$ & 16 & $34.8 \%$ & 76 & $39.2 \%$ & 92 & $41.8 \%$ \\
\hline & $\begin{array}{l}\text { Probably should not have } \\
\text { the right }\end{array}$ & 6 & $13.0 \%$ & 39 & $20.1 \%$ & 44 & $20.0 \%$ \\
\hline & $\begin{array}{l}\text { Definitely should not have } \\
\text { the right }\end{array}$ & 5 & $10.9 \%$ & 24 & $12.4 \%$ & 34 & $15.5 \%$ \\
\hline \multirow[t]{4}{*}{$\begin{array}{l}\text { Civil liberties - monitor } \\
\text { emails }\end{array}$} & $\begin{array}{l}\text { Definitely should have the } \\
\text { right }\end{array}$ & 8 & $17.4 \%$ & 15 & $7.7 \%$ & 21 & $9.5 \%$ \\
\hline & $\begin{array}{l}\text { Probably should have the } \\
\text { right }\end{array}$ & 12 & $26.1 \%$ & 52 & $26.7 \%$ & 45 & $20.3 \%$ \\
\hline & $\begin{array}{l}\text { Probably should not have } \\
\text { the right }\end{array}$ & 9 & $19.6 \%$ & 56 & $28.7 \%$ & 59 & $26.6 \%$ \\
\hline & $\begin{array}{l}\text { Definitely should not have } \\
\text { the right }\end{array}$ & 17 & $37.0 \%$ & 72 & $36.9 \%$ & 97 & $43.7 \%$ \\
\hline \multirow[t]{4}{*}{$\begin{array}{l}\text { Should govt collect citizen } \\
\text { info without knowledge }\end{array}$} & $\begin{array}{l}\text { Definitely should have the } \\
\text { right }\end{array}$ & 9 & $19.6 \%$ & 25 & $12.8 \%$ & 35 & $15.8 \%$ \\
\hline & $\begin{array}{l}\text { Probably should have the } \\
\text { right }\end{array}$ & 15 & $32.6 \%$ & 67 & $34.4 \%$ & 66 & $29.7 \%$ \\
\hline & $\begin{array}{l}\text { Probably should not have } \\
\text { the right }\end{array}$ & 13 & $28.3 \%$ & 52 & $26.7 \%$ & 54 & $24.3 \%$ \\
\hline & $\begin{array}{l}\text { Definitely should not have } \\
\text { the right }\end{array}$ & 9 & $19.6 \%$ & 51 & $26.2 \%$ & 67 & $30.2 \%$ \\
\hline \multirow{4}{*}{$\begin{array}{l}\text { Should govt collect } \\
\text { foreigner info without } \\
\text { knowledge }\end{array}$} & $\begin{array}{l}\text { Definitely should have the } \\
\text { right }\end{array}$ & 10 & $22.2 \%$ & 22 & $11.6 \%$ & 40 & $18.0 \%$ \\
\hline & $\begin{array}{l}\text { Probably should have the } \\
\text { right }\end{array}$ & 12 & $26.7 \%$ & 42 & $22.1 \%$ & 75 & $33.8 \%$ \\
\hline & $\begin{array}{l}\text { Probably should not have } \\
\text { the right }\end{array}$ & 14 & $31.1 \%$ & 81 & $42.6 \%$ & 53 & $23.9 \%$ \\
\hline & $\begin{array}{l}\text { Definitely should not have } \\
\text { the right }\end{array}$ & 9 & $20.0 \%$ & 45 & $23.7 \%$ & 54 & $24.3 \%$ \\
\hline
\end{tabular}


Table 10a-Confidence in the Legislature

\begin{tabular}{|c|c|c|c|c|c|c|c|}
\hline & & \multicolumn{6}{|c|}{ Confidence in congress } \\
\hline & & \multicolumn{2}{|c|}{ A GREAT DEAL } & \multicolumn{2}{|c|}{ ONLY SOME } & \multicolumn{2}{|c|}{ HARDLY ANY } \\
\hline & & Count & Column N \% & Count & Column N \% & Count & Column N \% \\
\hline \multirow{4}{*}{$\begin{array}{l}\text { Should authorities have } \\
\text { right to search ppl in the } \\
\text { street }\end{array}$} & $\begin{array}{l}\text { Definitely should have } \\
\text { right }\end{array}$ & 2 & $9.5 \%$ & 23 & $12.4 \%$ & 31 & $12.0 \%$ \\
\hline & $\begin{array}{l}\text { Probably should have } \\
\text { right }\end{array}$ & 3 & $14.3 \%$ & 43 & $23.1 \%$ & 41 & $15.9 \%$ \\
\hline & $\begin{array}{l}\text { Probably should not have } \\
\text { right }\end{array}$ & 6 & $28.6 \%$ & 49 & $26.3 \%$ & 75 & $29.1 \%$ \\
\hline & $\begin{array}{l}\text { Definitely should not have } \\
\text { right }\end{array}$ & 10 & $47.6 \%$ & 71 & $38.2 \%$ & 111 & $43.0 \%$ \\
\hline \multirow{4}{*}{$\begin{array}{l}\text { Should authorities have } \\
\text { right to tap phone } \\
\text { conveR'sation }\end{array}$} & $\begin{array}{l}\text { Definitely should have } \\
\text { right }\end{array}$ & 5 & $23.8 \%$ & 31 & $17.0 \%$ & 57 & $22.0 \%$ \\
\hline & $\begin{array}{l}\text { Probably should have } \\
\text { right }\end{array}$ & 3 & $14.3 \%$ & 53 & $29.1 \%$ & 68 & $26.3 \%$ \\
\hline & $\begin{array}{l}\text { Probably should not have } \\
\text { right }\end{array}$ & 2 & $9.5 \%$ & 49 & $26.9 \%$ & 58 & $22.4 \%$ \\
\hline & $\begin{array}{l}\text { Definitely should not have } \\
\text { right }\end{array}$ & 11 & $52.4 \%$ & 49 & $26.9 \%$ & 76 & $29.3 \%$ \\
\hline \multirow{4}{*}{$\begin{array}{l}\text { Should authorities have } \\
\text { right to detain the } \\
\text { suspected }\end{array}$} & $\begin{array}{l}\text { Definitely should have } \\
\text { right }\end{array}$ & 6 & $30.0 \%$ & 23 & $12.6 \%$ & 39 & $15.1 \%$ \\
\hline & $\begin{array}{l}\text { Probably should have } \\
\text { right }\end{array}$ & 4 & $20.0 \%$ & 47 & $25.7 \%$ & 47 & $18.1 \%$ \\
\hline & $\begin{array}{l}\text { Probably should not have } \\
\text { right }\end{array}$ & 5 & $25.0 \%$ & 56 & $30.6 \%$ & 76 & $29.3 \%$ \\
\hline & $\begin{array}{l}\text { Definitely should not have } \\
\text { right }\end{array}$ & 5 & $25.0 \%$ & 57 & $31.1 \%$ & 97 & $37.5 \%$ \\
\hline \multirow[t]{4}{*}{$\begin{array}{l}\text { Civil liberties - video } \\
\text { surveillance }\end{array}$} & $\begin{array}{l}\text { Definitely should have the } \\
\text { right }\end{array}$ & 9 & $42.9 \%$ & 50 & $27.0 \%$ & 64 & $24.9 \%$ \\
\hline & $\begin{array}{l}\text { Probably should have the } \\
\text { right }\end{array}$ & 4 & $19.0 \%$ & 86 & $46.5 \%$ & 95 & $37.0 \%$ \\
\hline & $\begin{array}{l}\text { Probably should not have } \\
\text { the right }\end{array}$ & 6 & $28.6 \%$ & 28 & $15.1 \%$ & 57 & $22.2 \%$ \\
\hline & $\begin{array}{l}\text { Definitely should not have } \\
\text { the right }\end{array}$ & 2 & $9.5 \%$ & 21 & $11.4 \%$ & 41 & $16.0 \%$ \\
\hline \multirow[t]{4}{*}{$\begin{array}{l}\text { Civil liberties - monitor } \\
\text { emails }\end{array}$} & $\begin{array}{l}\text { Definitely should have the } \\
\text { right }\end{array}$ & 4 & $19.0 \%$ & 15 & $8.0 \%$ & 25 & $9.7 \%$ \\
\hline & $\begin{array}{l}\text { Probably should have the } \\
\text { right }\end{array}$ & 3 & $14.3 \%$ & 46 & $24.6 \%$ & 60 & $23.3 \%$ \\
\hline & $\begin{array}{l}\text { Probably should not have } \\
\text { the right }\end{array}$ & 6 & $28.6 \%$ & 56 & $29.9 \%$ & 65 & $25.2 \%$ \\
\hline & $\begin{array}{l}\text { Definitely should not have } \\
\text { the right }\end{array}$ & 8 & $38.1 \%$ & 70 & $37.4 \%$ & 108 & $41.9 \%$ \\
\hline \multirow[t]{4}{*}{$\begin{array}{l}\text { Should govt collect citizen } \\
\text { info without knowledge }\end{array}$} & $\begin{array}{l}\text { Definitely should have the } \\
\text { right }\end{array}$ & 6 & $28.6 \%$ & 28 & $15.1 \%$ & 37 & $14.3 \%$ \\
\hline & $\begin{array}{l}\text { Probably should have the } \\
\text { right }\end{array}$ & 3 & $14.3 \%$ & 62 & $33.5 \%$ & 81 & $31.3 \%$ \\
\hline & $\begin{array}{l}\text { Probably should not have } \\
\text { the right }\end{array}$ & 4 & $19.0 \%$ & 53 & $28.6 \%$ & 63 & $24.3 \%$ \\
\hline & $\begin{array}{l}\text { Definitely should not have } \\
\text { the right }\end{array}$ & 8 & $38.1 \%$ & 42 & $22.7 \%$ & 78 & $30.1 \%$ \\
\hline \multirow{4}{*}{$\begin{array}{l}\text { Should govt collect } \\
\text { foreigner info without } \\
\text { knowledge }\end{array}$} & $\begin{array}{l}\text { Definitely should have the } \\
\text { right }\end{array}$ & 7 & $33.3 \%$ & 22 & $12.2 \%$ & 44 & $17.1 \%$ \\
\hline & $\begin{array}{l}\text { Probably should have the } \\
\text { right }\end{array}$ & 2 & $9.5 \%$ & 44 & $24.4 \%$ & 83 & $32.2 \%$ \\
\hline & $\begin{array}{l}\text { Probably should not have } \\
\text { the right }\end{array}$ & 4 & $19.0 \%$ & 72 & $40.0 \%$ & 72 & $27.9 \%$ \\
\hline & $\begin{array}{l}\text { Definitely should not have } \\
\text { the right }\end{array}$ & 8 & $38.1 \%$ & 42 & $23.3 \%$ & 59 & $22.9 \%$ \\
\hline
\end{tabular}


Table 11a-Confidence in the Supreme Court

\begin{tabular}{|c|c|c|c|c|c|c|c|}
\hline & & \multicolumn{6}{|c|}{ Confid. in united states supreme court } \\
\hline & & \multicolumn{2}{|c|}{ A GREAT DEAL } & \multicolumn{2}{|c|}{ ONLY SOME } & \multicolumn{2}{|c|}{ HARDLY ANY } \\
\hline & & Count & Column N \% & Count & Column N \% & Count & Column N \% \\
\hline \multirow{4}{*}{$\begin{array}{l}\text { Should authorities have } \\
\text { right to search ppl in the } \\
\text { street }\end{array}$} & $\begin{array}{l}\text { Definitely should have } \\
\text { right }\end{array}$ & 14 & $13.5 \%$ & 26 & $10.6 \%$ & 16 & $14.5 \%$ \\
\hline & $\begin{array}{l}\text { Probably should have } \\
\text { right }\end{array}$ & 16 & $15.4 \%$ & 51 & $20.8 \%$ & 19 & $17.3 \%$ \\
\hline & $\begin{array}{l}\text { Probably should not have } \\
\text { right }\end{array}$ & 33 & $31.7 \%$ & 74 & $30.2 \%$ & 23 & $20.9 \%$ \\
\hline & $\begin{array}{l}\text { Definitely should not have } \\
\text { right }\end{array}$ & 41 & $39.4 \%$ & 94 & $38.4 \%$ & 52 & $47.3 \%$ \\
\hline \multirow{4}{*}{$\begin{array}{l}\text { Should authorities have } \\
\text { right to tap phone } \\
\text { conveR'sation }\end{array}$} & $\begin{array}{l}\text { Definitely should have } \\
\text { right }\end{array}$ & 22 & $21.2 \%$ & 44 & $18.0 \%$ & 28 & $25.5 \%$ \\
\hline & $\begin{array}{l}\text { Probably should have } \\
\text { right }\end{array}$ & 26 & $25.0 \%$ & 74 & $30.3 \%$ & 23 & $20.9 \%$ \\
\hline & $\begin{array}{l}\text { Probably should not have } \\
\text { right }\end{array}$ & 23 & $22.1 \%$ & 60 & $24.6 \%$ & 26 & $23.6 \%$ \\
\hline & $\begin{array}{l}\text { Definitely should not have } \\
\text { right }\end{array}$ & 33 & $31.7 \%$ & 66 & $27.0 \%$ & 33 & $30.0 \%$ \\
\hline \multirow{4}{*}{$\begin{array}{l}\text { Should authorities have } \\
\text { right to detain the } \\
\text { suspected }\end{array}$} & $\begin{array}{l}\text { Definitely should have } \\
\text { right }\end{array}$ & 11 & $10.7 \%$ & 31 & $12.8 \%$ & 26 & $23.4 \%$ \\
\hline & $\begin{array}{l}\text { Probably should have } \\
\text { right }\end{array}$ & 21 & $20.4 \%$ & 56 & $23.0 \%$ & 19 & $17.1 \%$ \\
\hline & $\begin{array}{l}\text { Probably should not have } \\
\text { right }\end{array}$ & 31 & $30.1 \%$ & 79 & $32.5 \%$ & 25 & $22.5 \%$ \\
\hline & $\begin{array}{l}\text { Definitely should not have } \\
\text { right }\end{array}$ & 40 & $38.8 \%$ & 77 & $31.7 \%$ & 41 & $36.9 \%$ \\
\hline \multirow[t]{4}{*}{$\begin{array}{l}\text { Civil liberties - video } \\
\text { surveillance }\end{array}$} & $\begin{array}{l}\text { Definitely should have the } \\
\text { right }\end{array}$ & 37 & $35.2 \%$ & 57 & $23.4 \%$ & 29 & $26.4 \%$ \\
\hline & $\begin{array}{l}\text { Probably should have the } \\
\text { right }\end{array}$ & 40 & $38.1 \%$ & 103 & $42.2 \%$ & 40 & $36.4 \%$ \\
\hline & $\begin{array}{l}\text { Probably should not have } \\
\text { the right }\end{array}$ & 19 & $18.1 \%$ & 51 & $20.9 \%$ & 19 & $17.3 \%$ \\
\hline & $\begin{array}{l}\text { Definitely should not have } \\
\text { the right }\end{array}$ & 9 & $8.6 \%$ & 33 & $13.5 \%$ & 22 & $20.0 \%$ \\
\hline \multirow[t]{4}{*}{$\begin{array}{l}\text { Civil liberties - monitor } \\
\text { emails }\end{array}$} & $\begin{array}{l}\text { Definitely should have the } \\
\text { right }\end{array}$ & 10 & $9.5 \%$ & 15 & $6.1 \%$ & 19 & $17.3 \%$ \\
\hline & $\begin{array}{l}\text { Probably should have the } \\
\text { right }\end{array}$ & 31 & $29.5 \%$ & 59 & $24.0 \%$ & 20 & $18.2 \%$ \\
\hline & $\begin{array}{l}\text { Probably should not have } \\
\text { the right }\end{array}$ & 25 & $23.8 \%$ & 75 & $30.5 \%$ & 22 & $20.0 \%$ \\
\hline & $\begin{array}{l}\text { Definitely should not have } \\
\text { the right }\end{array}$ & 39 & $37.1 \%$ & 97 & $39.4 \%$ & 49 & $44.5 \%$ \\
\hline \multirow[t]{4}{*}{$\begin{array}{l}\text { Should govt collect citizen } \\
\text { info without knowledge }\end{array}$} & $\begin{array}{l}\text { Definitely should have the } \\
\text { right }\end{array}$ & 18 & $17.3 \%$ & 33 & $13.4 \%$ & 19 & $17.3 \%$ \\
\hline & $\begin{array}{l}\text { Probably should have the } \\
\text { right }\end{array}$ & 32 & $30.8 \%$ & 82 & $33.2 \%$ & 34 & $30.9 \%$ \\
\hline & $\begin{array}{l}\text { Probably should not have } \\
\text { the right }\end{array}$ & 26 & $25.0 \%$ & 72 & $29.1 \%$ & 21 & $19.1 \%$ \\
\hline & $\begin{array}{l}\text { Definitely should not have } \\
\text { the right }\end{array}$ & 28 & $26.9 \%$ & 60 & $24.3 \%$ & 36 & $32.7 \%$ \\
\hline \multirow{4}{*}{$\begin{array}{l}\text { Should govt collect } \\
\text { foreigner info without } \\
\text { knowledge }\end{array}$} & $\begin{array}{l}\text { Definitely should have the } \\
\text { right }\end{array}$ & 15 & $14.6 \%$ & 35 & $14.4 \%$ & 22 & $20.2 \%$ \\
\hline & $\begin{array}{l}\text { Probably should have the } \\
\text { right }\end{array}$ & 26 & $25.2 \%$ & 72 & $29.6 \%$ & 30 & $27.5 \%$ \\
\hline & $\begin{array}{l}\text { Probably should not have } \\
\text { the right }\end{array}$ & 31 & $30.1 \%$ & 91 & $37.4 \%$ & 26 & $23.9 \%$ \\
\hline & $\begin{array}{l}\text { Definitely should not have } \\
\text { the right }\end{array}$ & 31 & $30.1 \%$ & 45 & $18.5 \%$ & 31 & $28.4 \%$ \\
\hline
\end{tabular}


Table 12: Multiple Regression DV-STOPRNDM

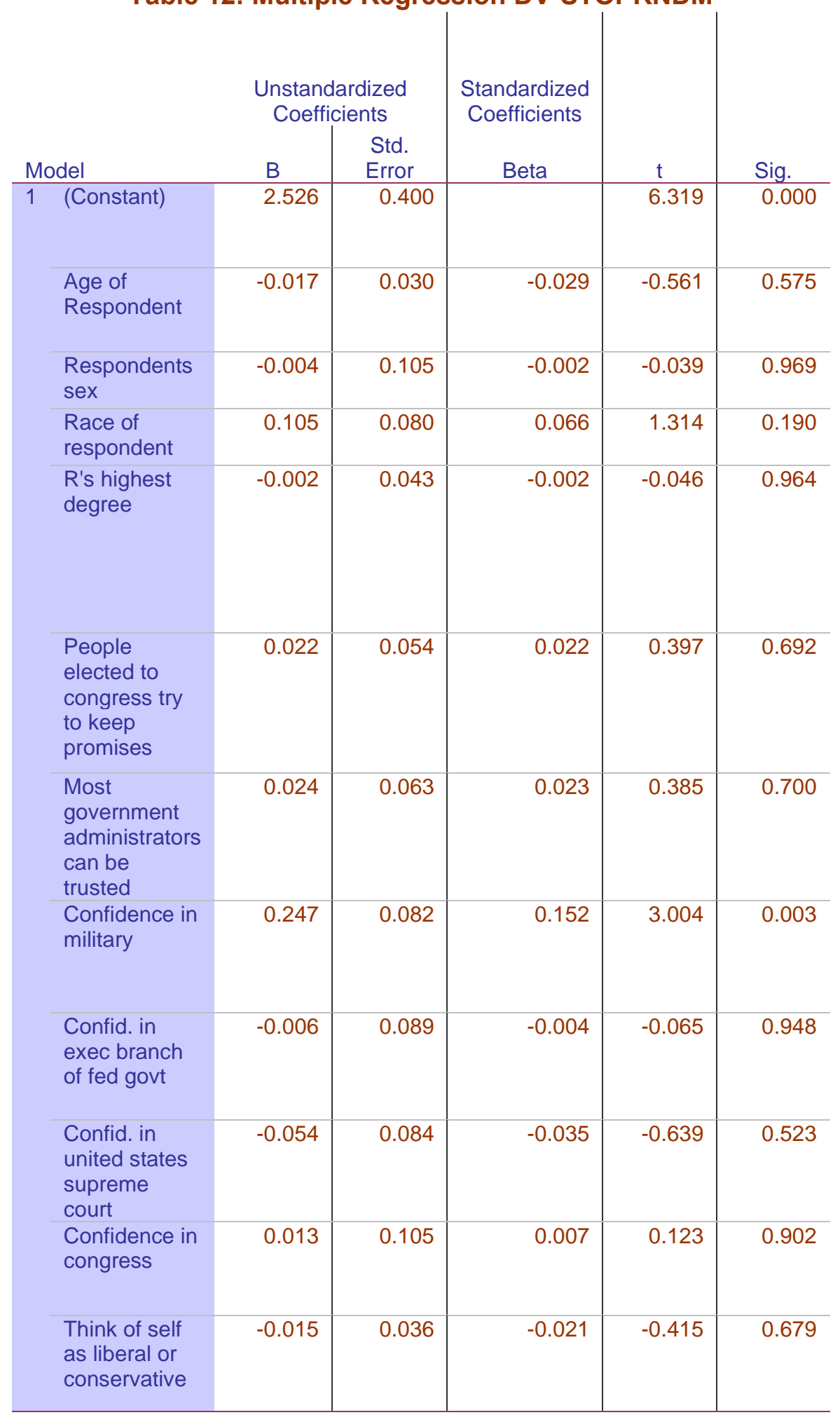

a. Dependent Variable: Should authorities have right to search ppl in the street 
Table 13: Multiple Regression DV-TAPPHONE

\begin{tabular}{|c|c|c|c|c|c|}
\hline \multirow[b]{2}{*}{ Model } & \multicolumn{2}{|c|}{$\begin{array}{l}\text { Unstandardized } \\
\text { Coefficients }\end{array}$} & \multirow{2}{*}{$\begin{array}{c}\text { Standardized } \\
\text { Coefficients } \\
\text { Beta }\end{array}$} & \multirow[b]{2}{*}{$\mathrm{t}$} & \multirow[b]{2}{*}{ Sig. } \\
\hline & B & $\begin{array}{l}\text { Std. } \\
\text { Error }\end{array}$ & & & \\
\hline $1 \quad$ (Constant) & 2.625 & 0.426 & & 6.159 & 0.000 \\
\hline $\begin{array}{l}\text { Age of } \\
\text { Respondent }\end{array}$ & -0.013 & 0.032 & -0.020 & -0.392 & 0.695 \\
\hline $\begin{array}{l}\text { Respondents } \\
\text { sex }\end{array}$ & -0.038 & 0.112 & -0.016 & -0.338 & 0.736 \\
\hline $\begin{array}{l}\text { Race of } \\
\text { respondent }\end{array}$ & 0.118 & 0.085 & 0.070 & 1.392 & 0.165 \\
\hline $\begin{array}{l}\text { R's highest } \\
\text { degree }\end{array}$ & -0.072 & 0.046 & -0.079 & -1.572 & 0.117 \\
\hline $\begin{array}{l}\text { People } \\
\text { elected to } \\
\text { congress try } \\
\text { to keep } \\
\text { promises }\end{array}$ & -0.006 & 0.057 & -0.006 & -0.105 & 0.916 \\
\hline $\begin{array}{l}\text { Most } \\
\text { government } \\
\text { administrators } \\
\text { can be } \\
\text { trusted }\end{array}$ & 0.031 & 0.068 & 0.027 & 0.460 & 0.646 \\
\hline $\begin{array}{l}\text { Confidence in } \\
\text { military }\end{array}$ & 0.273 & 0.087 & 0.158 & 3.124 & 0.002 \\
\hline $\begin{array}{l}\text { Confid. in } \\
\text { exec branch } \\
\text { of fed govt }\end{array}$ & 0.049 & 0.096 & 0.029 & 0.510 & 0.610 \\
\hline $\begin{array}{l}\text { Confid. in } \\
\text { united states } \\
\text { supreme } \\
\text { court }\end{array}$ & -0.076 & 0.090 & -0.046 & -0.845 & 0.399 \\
\hline $\begin{array}{l}\text { Confidence in } \\
\text { congress }\end{array}$ & -0.135 & 0.112 & -0.072 & -1.206 & 0.229 \\
\hline $\begin{array}{l}\text { Think of self } \\
\text { as liberal or } \\
\text { conservative }\end{array}$ & -0.020 & 0.038 & -0.027 & -0.530 & 0.597 \\
\hline
\end{tabular}

a. Dependent Variable: Should authorities have right to tap phone Conversation 
Table 14: Multiple Regression DV-WOTRIAL

\begin{tabular}{|c|c|c|c|c|c|c|}
\hline \multicolumn{2}{|c|}{ Model } & \multicolumn{2}{|c|}{$\begin{array}{l}\text { Unstandardized } \\
\text { Coefficients }\end{array}$} & $\begin{array}{c}\text { Standardized } \\
\text { Coefficients } \\
\text { Beta }\end{array}$ & $t$ & Sig. \\
\hline & (Constant) & 2.810 & 0.398 & & 7.069 & 0.000 \\
\hline & $\begin{array}{l}\text { Age of } \\
\text { Respondent }\end{array}$ & -0.086 & 0.030 & -0.142 & -2.878 & 0.004 \\
\hline & $\begin{array}{l}\text { Respondents } \\
\text { sex }\end{array}$ & -0.212 & 0.104 & -0.096 & -2.041 & 0.042 \\
\hline & $\begin{array}{l}\text { Race of } \\
\text { respondent }\end{array}$ & -0.136 & 0.080 & -0.083 & -1.703 & 0.089 \\
\hline & $\begin{array}{l}\text { R's highest } \\
\text { degree }\end{array}$ & 0.065 & 0.043 & 0.074 & 1.517 & 0.130 \\
\hline & $\begin{array}{l}\text { People } \\
\text { elected to } \\
\text { congress try } \\
\text { to keep } \\
\text { promises }\end{array}$ & 0.057 & 0.054 & 0.056 & 1.058 & 0.291 \\
\hline & $\begin{array}{l}\text { Most } \\
\text { government } \\
\text { administrators } \\
\text { can be } \\
\text { trusted }\end{array}$ & -0.046 & 0.063 & -0.042 & -0.734 & 0.463 \\
\hline & $\begin{array}{l}\text { Confidence in } \\
\text { military }\end{array}$ & 0.342 & 0.081 & 0.205 & 4.205 & 0.000 \\
\hline & $\begin{array}{l}\text { Confid. in } \\
\text { exec branch } \\
\text { of fed govt }\end{array}$ & 0.073 & 0.090 & 0.045 & 0.805 & 0.421 \\
\hline & $\begin{array}{l}\text { Confid. in } \\
\text { united states } \\
\text { supreme } \\
\text { court }\end{array}$ & -0.175 & 0.083 & -0.112 & -2.104 & 0.036 \\
\hline & $\begin{array}{l}\text { Confidence in } \\
\text { congress }\end{array}$ & 0.140 & 0.104 & 0.076 & 1.341 & 0.181 \\
\hline & $\begin{array}{l}\text { Think of self } \\
\text { as liberal or } \\
\text { conservative }\end{array}$ & -0.001 & 0.036 & -0.002 & -0.031 & 0.975 \\
\hline
\end{tabular}

a. Dependent Variable: Should authorities have right to detain the suspected 
Table 15: Multiple Regression DV-CCTV

\begin{tabular}{|c|c|c|c|c|c|}
\hline Model & $\begin{array}{l}\text { Unstanc } \\
\text { Coeff } \\
\text { B }\end{array}$ & $\begin{array}{l}\text { dized } \\
\text { nts } \\
\text { Std. } \\
\text { Error }\end{array}$ & $\begin{array}{c}\text { Standardized } \\
\text { Coefficients } \\
\text { Beta } \\
\end{array}$ & $\mathrm{t}$ & Sig. \\
\hline 1 (Constant) & 2.407 & 0.371 & & 6.488 & 0.000 \\
\hline $\begin{array}{l}\text { Age of } \\
\text { Respondent }\end{array}$ & -0.012 & 0.028 & -0.022 & -0.435 & 0.664 \\
\hline $\begin{array}{l}\text { Respondents } \\
\text { sex }\end{array}$ & -0.224 & 0.097 & -0.111 & -2.304 & 0.022 \\
\hline $\begin{array}{l}\text { Race of } \\
\text { respondent }\end{array}$ & 0.005 & 0.074 & 0.003 & 0.065 & 0.948 \\
\hline $\begin{array}{l}\text { R's highest } \\
\text { degree }\end{array}$ & -0.118 & 0.040 & -0.148 & -2.967 & 0.003 \\
\hline $\begin{array}{l}\text { People } \\
\text { elected to } \\
\text { congress try } \\
\text { to keep } \\
\text { promises }\end{array}$ & -0.054 & 0.050 & -0.060 & -1.084 & 0.279 \\
\hline $\begin{array}{l}\text { Most } \\
\text { government } \\
\text { administrators } \\
\text { can be } \\
\text { trusted }\end{array}$ & -0.044 & 0.059 & -0.043 & -0.740 & 0.460 \\
\hline $\begin{array}{l}\text { Confidence in } \\
\text { military }\end{array}$ & 0.074 & 0.076 & 0.048 & 0.967 & 0.334 \\
\hline $\begin{array}{l}\text { Confid. in } \\
\text { exec branch } \\
\text { of fed govt }\end{array}$ & 0.107 & 0.083 & 0.072 & 1.292 & 0.197 \\
\hline $\begin{array}{l}\text { Confid. in } \\
\text { united states } \\
\text { supreme } \\
\text { court }\end{array}$ & 0.056 & 0.078 & 0.039 & 0.711 & 0.477 \\
\hline $\begin{array}{l}\text { Confidence in } \\
\text { congress }\end{array}$ & 0.151 & 0.098 & 0.091 & 1.545 & 0.123 \\
\hline $\begin{array}{l}\text { Think of self } \\
\text { as liberal or } \\
\text { conservative }\end{array}$ & -0.030 & 0.033 & -0.046 & -0.919 & 0.358 \\
\hline
\end{tabular}

a. Dependent Variable: Civil liberties - video surveillance 
Table 16: Multiple Regression DV-EMONITOR

\begin{tabular}{|c|c|c|c|c|c|}
\hline Model & $\begin{array}{l}\text { Unstanc } \\
\text { Coeff } \\
\text { B }\end{array}$ & $\begin{array}{l}\text { dized } \\
\text { ants } \\
\text { Std. } \\
\text { Error }\end{array}$ & $\begin{array}{c}\text { Standardized } \\
\text { Coefficients } \\
\text { Beta } \\
\end{array}$ & $\mathrm{t}$ & Sig. \\
\hline 1 (Constant) & 3.422 & 0.387 & & 8.850 & 0.000 \\
\hline $\begin{array}{l}\text { Age of } \\
\text { Respondent }\end{array}$ & -0.028 & 0.029 & -0.048 & -0.947 & 0.344 \\
\hline $\begin{array}{l}\text { Respondents } \\
\text { sex }\end{array}$ & -0.159 & 0.101 & -0.076 & -1.571 & 0.117 \\
\hline $\begin{array}{l}\text { Race of } \\
\text { respondent }\end{array}$ & -0.036 & 0.077 & -0.023 & -0.464 & 0.643 \\
\hline $\begin{array}{l}\text { R's highest } \\
\text { degree }\end{array}$ & -0.119 & 0.042 & -0.143 & -2.863 & 0.004 \\
\hline $\begin{array}{l}\text { People } \\
\text { elected to } \\
\text { congress try } \\
\text { to keep } \\
\text { promises }\end{array}$ & -0.051 & 0.052 & -0.054 & -0.974 & 0.331 \\
\hline $\begin{array}{l}\text { Most } \\
\text { government } \\
\text { administrators } \\
\text { can be } \\
\text { trusted }\end{array}$ & 0.082 & 0.061 & 0.078 & 1.338 & 0.182 \\
\hline $\begin{array}{l}\text { Confidence in } \\
\text { military }\end{array}$ & 0.131 & 0.079 & 0.083 & 1.652 & 0.099 \\
\hline $\begin{array}{l}\text { Confid. in } \\
\text { exec branch } \\
\text { of fed govt }\end{array}$ & 0.149 & 0.086 & 0.097 & 1.722 & 0.086 \\
\hline $\begin{array}{l}\text { Confid. in } \\
\text { united states } \\
\text { supreme } \\
\text { court }\end{array}$ & -0.124 & 0.081 & -0.083 & -1.517 & 0.130 \\
\hline $\begin{array}{l}\text { Confidence in } \\
\text { congress }\end{array}$ & -0.005 & 0.102 & -0.003 & -0.052 & 0.958 \\
\hline $\begin{array}{l}\text { Think of self } \\
\text { as liberal or } \\
\text { conservative }\end{array}$ & -0.058 & 0.035 & -0.084 & -1.688 & 0.092 \\
\hline
\end{tabular}

a. Dependent Variable: Civil liberties - monitor emails 
Table 17: Multiple Regression DV-GIVINFUSA

\begin{tabular}{|c|c|c|c|c|c|}
\hline Model & $\begin{array}{l}\text { Unstanc } \\
\text { Coeff } \\
\text { B }\end{array}$ & $\begin{array}{l}\text { dized } \\
\text { nts } \\
\text { Std. } \\
\text { Error }\end{array}$ & $\begin{array}{c}\text { Standardized } \\
\text { Coefficients } \\
\text { Beta } \\
\end{array}$ & $\mathrm{t}$ & Sig. \\
\hline $\begin{array}{ll}1 & \text { (Constant) }\end{array}$ & 2.713 & 0.392 & & 6.925 & 0.000 \\
\hline $\begin{array}{l}\text { Age of } \\
\text { Respondent }\end{array}$ & -0.066 & 0.029 & -0.111 & -2.230 & 0.026 \\
\hline $\begin{array}{l}\text { Respondents } \\
\text { sex }\end{array}$ & -0.072 & 0.103 & -0.034 & -0.706 & 0.480 \\
\hline $\begin{array}{l}\text { Race of } \\
\text { respondent }\end{array}$ & -0.093 & 0.078 & -0.059 & -1.188 & 0.235 \\
\hline $\begin{array}{l}\text { R's highest } \\
\text { degree }\end{array}$ & -0.132 & 0.042 & -0.155 & -3.142 & 0.002 \\
\hline $\begin{array}{l}\text { People } \\
\text { elected to } \\
\text { congress try } \\
\text { to keep } \\
\text { promises }\end{array}$ & 0.034 & 0.053 & 0.035 & 0.650 & 0.516 \\
\hline $\begin{array}{l}\text { Most } \\
\text { government } \\
\text { administrators } \\
\text { can be } \\
\text { trusted }\end{array}$ & 0.037 & 0.062 & 0.035 & 0.599 & 0.549 \\
\hline $\begin{array}{l}\text { Confidence in } \\
\text { military }\end{array}$ & 0.275 & 0.080 & 0.169 & 3.421 & 0.001 \\
\hline $\begin{array}{l}\text { Confid. in } \\
\text { exec branch } \\
\text { of fed govt }\end{array}$ & 0.028 & 0.088 & 0.018 & 0.323 & 0.747 \\
\hline $\begin{array}{l}\text { Confid. in } \\
\text { united states } \\
\text { supreme } \\
\text { court }\end{array}$ & -0.100 & 0.082 & -0.065 & -1.210 & 0.227 \\
\hline $\begin{array}{l}\text { Confidence in } \\
\text { congress }\end{array}$ & 0.051 & 0.103 & 0.029 & 0.497 & 0.619 \\
\hline $\begin{array}{l}\text { Think of self } \\
\text { as liberal or } \\
\text { conservative }\end{array}$ & -0.006 & 0.035 & -0.008 & -0.168 & 0.867 \\
\hline
\end{tabular}

a. Dependent Variable: Should govt collect citizen info without knowledge 
Table 18: Multiple Regression DV-GIVINFFOR

\begin{tabular}{|c|c|c|c|c|c|}
\hline \multirow[b]{2}{*}{ Model } & \multicolumn{2}{|c|}{$\begin{array}{l}\text { Unstandardized } \\
\text { Coefficients }\end{array}$} & \multirow{2}{*}{$\begin{array}{c}\text { Standardized } \\
\text { Coefficients } \\
\text { Beta }\end{array}$} & \multirow[b]{2}{*}{$\mathrm{t}$} & \multirow[b]{2}{*}{ Sig. } \\
\hline & $\mathrm{B}$ & $\begin{array}{l}\text { Std. } \\
\text { Error }\end{array}$ & & & \\
\hline $\begin{array}{ll}1 & \text { (Constant) }\end{array}$ & 3.273 & 0.385 & & 8.506 & 0.000 \\
\hline $\begin{array}{l}\text { Age of } \\
\text { Respondent }\end{array}$ & -0.116 & 0.029 & -0.201 & -4.014 & 0.000 \\
\hline $\begin{array}{l}\text { Respondents } \\
\text { sex }\end{array}$ & 0.119 & 0.101 & 0.056 & 1.180 & 0.239 \\
\hline $\begin{array}{l}\text { Race of } \\
\text { respondent }\end{array}$ & -0.052 & 0.077 & -0.033 & -0.672 & 0.502 \\
\hline $\begin{array}{l}\text { R's highest } \\
\text { degree }\end{array}$ & -0.085 & 0.042 & -0.100 & -2.039 & 0.042 \\
\hline $\begin{array}{l}\text { People } \\
\text { elected to } \\
\text { congress try } \\
\text { to keep } \\
\text { promises }\end{array}$ & -0.037 & 0.052 & -0.039 & -0.712 & 0.477 \\
\hline $\begin{array}{l}\text { Most } \\
\text { government } \\
\text { administrators } \\
\text { can be } \\
\text { trusted }\end{array}$ & -0.052 & 0.061 & -0.049 & -0.849 & 0.397 \\
\hline $\begin{array}{l}\text { Confidence in } \\
\text { military }\end{array}$ & 0.239 & 0.079 & 0.151 & 3.043 & 0.002 \\
\hline $\begin{array}{l}\text { Confid. in } \\
\text { exec branch } \\
\text { of fed govt }\end{array}$ & -0.008 & 0.086 & -0.005 & -0.096 & 0.924 \\
\hline $\begin{array}{l}\text { Confid. in } \\
\text { united states } \\
\text { supreme } \\
\text { court }\end{array}$ & -0.051 & 0.081 & -0.034 & -0.627 & 0.531 \\
\hline $\begin{array}{l}\text { Confidence in } \\
\text { congress }\end{array}$ & -0.003 & 0.101 & -0.002 & -0.027 & 0.978 \\
\hline $\begin{array}{l}\text { Think of self } \\
\text { as liberal or } \\
\text { conservative }\end{array}$ & -0.032 & 0.034 & -0.047 & -0.954 & 0.341 \\
\hline
\end{tabular}

a. Dependent Variable: Should govt collect foreigner info without knowledge 